\title{
ANALISIS DESKRIPTIF ATAS LITERASI KEUANGAN PADA KELOMPOK TANI
}

\author{
Minto Yuwono \\ yuwono.minto@yahoo.com \\ Budi Suharjo \\ Bunasor Sanim \\ Rita Nurmalina \\ Institut Pertanian Bogor
}

\begin{abstract}
Low levels of inclusive finance Indonesia is caused by low levels of $62 \%$ of Indonesian society inclusive finance, where the majority of work in the informal sector (including farmers). This study aims to identify and descriptively analyze the farmers' knowledge related to finance or financial literacy that allows individuals to make effective decisions. The study was conducted using Structural Equation Modeling (SEM). The research location includes several centers of agriculture on the island of Java covering 3 provinces ie covering West Java, Central Java and East Java. In managing finance, only few farmers who use financial institutions to save or borrow. For the borrowing of funds in a certain amount and emergency, the farmers rely more on borrowing from friends or family or relatives. Less than $6 \%$ of farmers who plan the expenditure budget of households and implement them consistently. In this study also found that there is a significant and positive relationship between knowledge of financial institutions with a level of use of products of financial institutions. The higher the level of knowledge of farmers to financial institutions, the higher the level of use of the product of financial institutions.
\end{abstract}

Key words : literacy, profile, knowledge, correlation, financial inclusion

\begin{abstract}
ABSTRAK
Rendahnya tingkat keuangan inklusif Indonesia disebabkan oleh rendahnya tingkat keuangan inklusif dari 62\% masyarakat Indonesia, dimana mayoritas bekerja pada sektor informal (diantaranya adalah petani). Penelitian ini bertujuan untuk mengidentifikasi dan menganalisis secara deskriptif tingkat pengetahuan petani terkait keuangan atau literasi keuangan yang memungkinkan individu untuk membuat keputusan efektif. Penelitian dilakukan dengan menggunakan Structural Equation Modelling (SEM). Lokasi penelitian meliputi beberapa sentra pertanian di pulau Jawa meliputi 3 Provinsi yakni meliputi Jawa Barat, Jawa Tengah dan Jawa Timur. Dalam mengelola keuangan baru sebagian kecil petani yang menggunakan lembaga keuangan baik untuk menyimpan maupun meminjam. Untuk peminjaman dana dalam jumlah tertentu dan bersifat mendadak petani lebih mengandalkan pinjam dari teman atau keluarga/famili. Tidak lebih dari $6 \%$ petani yang merencanakan pengeluaran rumah tangga dan menjalankannya secara konsisten. Pada penelitian ini juga didapatkan bahwa terdapat hubungan yang significant dan positif antara pengetahuan terhadap lembaga keuangan dengan tingkat penggunaan produk lembaga keuangan. Semakin tinggi tingkat pengetahuan petani terhadap lembaga keuangan maka semakin tinggi pula tingkat penggunaan produk lembaga keuangan.
\end{abstract}

Kata kunci : literasi, profil, pengetahuan, korelasi, inklusi keuangan

\section{PENDAHULUAN}

Secara umum kebijakan yang paling efisien untuk mengatasi kemiskinan adalah melalui pertumbuhan ekonomi yang tinggi dan berkelanjutan. Percepatan pertumbuhan ekonomi berperan sebagai syarat dasar yang paling strategis bagi peningkatan kualitas kehidupan rakyat, termasuk pengetahuan yang memungkinkan individu untuk membuat keputusan efektif terhadap investasi- 
nya agar dapat meningkatkan keuangannya. Penelitian yang dilakukan oleh BI yang melibatkan 2.612 responden yang tersebar di 10 propinsi di Indonesia, mengungkapkan bahwa, terdapat perbedaan Indeks Keuangan Inklusif (IKI) yang signifikan dari sisi demografi. Aspek demografi yang meliputi tingkat pengeluaran Individu (Sosial Ekonomi Status, SES), usia, pendidikan, serta pekerjaan (Bank Indonesia, 2014) menunjukkan bahwa, semakin tinggi tingkat pendidikan seseorang peluang mendapatkan pekerjaan formal semakin tinggi, dan tingkat pendapatannya yang diproksi melalui pengeluaran individu juga semakin tinggi. Kelompok masyarakat ini memiliki IKI yang tinggi. Sebaliknya masyarakat dengan tingkat pendidikan rendah dan bekerja pada sektor informal memiliki tingkat pengeluaran individu relatif rendah, dampaknya adalah nilai IKI-nyapun relatif rendah.

Masyarakat dengan pekerjaan informal diantaranya adalah petani dengan lahan tidak lebih dari 0,5 ha, merupakan bagian dari masyarakat dengan SES D (26\%) dan E $(36 \%)$ atau tingkat pengeluarannya per bulan tidak lebih dari Rp 1,25 juta. Kelompok masyarakat ini nilai IKI-nya terendah masing-masing 18\% (SES-D) dan 14\% (SESE). Fakta menarik lain adalah masyarakat dengan usia di atas 45 tahun nilai IKI-nya tidak lebih dari 23\%. Menyimak hasil penelitian ini dapatlah disimpulkan bahwa, rendahnya tingkat keuangan inklusif Indonesia disebabkan oleh rendahnya tingkat keuangan inklusif dari $62 \%$ masyarakat Indonesia, dimana mayoritas bekerja pada sektor informal (diantaranya adalah petani), dengan tingkat pengeluaran tidak lebih dari Rp 1.250.000 per bulan.

Untuk meningkatkan keuangan literasi kelompok tani, disadari bukan suatu hal yang mudah, mengingat permasalahan utama yang dihadapi kelompok ini adalah tidak adanya rendahnya pengetahuan mereka terhadap pengetahuan dalam pengelolaan keuangan, oleh karenanya upaya "memaksa" mereka untuk mengelola dana yang terbatas melalui pemanfaatan produk dan layanan keuangan menjadi suatu hal yang perlu dilakukan. Untuk itu pemahaman yang mendalam mengenai perilaku petani dalam pengelolaan keuangannya, serta minatnya untuk terinklusi pada lembaga keuangan formal perlu dirumuskan. Selain itu berbagai hambatan yang mungkin muncul perlu dielaborasi secara optimal agar dapat dirumuskan strategi yang komprehensif guna meningkatkan minat petani untuk menggunakan produk atau jasa lembaga keuangan formal, sebagai pijakan dalam meningkatkan keuangan inklusif. Berdasarkan latar belakang dan permasalahan di atas, tujuan penelitian ini adalah mengidentifikasi dan menganalisis secara deskriptif tingkat pengetahuan petani terkait keuangan atau literasi keuangan yang memungkinkan individu untuk membuat keputusan efektif.

\section{TINJAUAN TEORETIS}

Literasi keuangan adalah seperangkat keterampilan, pengetahuan yang memungkinkan individu mengelola keuangan pribadi dengan lebih baik (OJK, 2015). Literasi keuangan sebagai upaya untuk meningkatkan kepekaan masyarakat terhadap sektor jasa keuangan, yang diawali dengan mengetahui, kemudian meyakini, hingga menjadi terampil untuk terlibat aktif, dengan kata lain mencapai masyarakat yang memiliki tingkat literasi baik (well literate) pada sektor jasa keuangan; yakni bidang perbankan, perasuransian, lembaga pembiayaan, dana pensiun, pasar modal, dan pegadaian.

Menurut Huston (2010), bahwa literasi keuangan sebagai kemampuan untuk memahami kondisi keuangan serta konsepkonsep keuangan dan untuk merubah pengetahuan itu secara tepat kedalam perilaku. The President's Advisory Council On Financial Literacy (2013) juga mendefinisikan bahwa literasi keuangan sebagai kemampuan untuk menggunakan pengetahuan serta keahlian untuk mengelola sumber daya keuangan agar tercapai kesejahteraan. Menurut Lembaga Otoritas Jasa Keuangan (2015) menyatakan bahwa secara definisi literasi 
diartikan sebagai kemampuan memahami, jadi literasi keuangan adalah kemampuan mengelola dana yang dimiliki agar berkembang dan hidup bisa lebih sejahtera dimasa yang akan datang. Studi tentang literasi keuangan sudah banyak dilakukan (Huston, 2010), tapi justru di negara-negara maju seperti USA.

Chen dan Volpe (1998) mengartikan literasi keuangan sebagai pengetahuan untuk mengelola keuangan dalam pengambilan keputusan keuangan. Mereka menyampaikan bahwa dalam personal final sebagai proses pengendalian keuangan keluarga maka pemahaman terhadap instrumen keuangan yang ada dalam lembaga keuangan seperti simpanan di Bank, asuransi dan investasi akan sangat menentukan pilihan dan besarnya kesejahteraan yang terjadi dalam masyarakat.

Misi penting dari program literasi keuangan adalah untuk melakukan edukasi di bidang keuangan kepada masyarakat Indonesia agar dapat mengelola keuangan secara cerdas, sehingga rendahnya pengetahuan tentang industri keuangan dapat diatasi dan masyarakat tidak mudah tertipu pada produk-produk investasi yang menawarkan keuntungan tinggi dalam jangka pendek tanpa mempertimbangkan risikonya. Perlunya pemahaman masyarakat tentang produk dan layanan yang ditawarkan oleh lembaga jasa keuangan, maka program strategi nasional literasi keuangan mencanangkan tiga pilar utama. Pertama, mengedepankan program edukasi dan kampanye nasional literasi keuangan. Kedua, berbentuk penguatan infrastruktur literasi keuangan. Ketiga, berbicara tentang pengembangan produk dan layanan jasa keuangan yang terjangkau. Penerapan ketiga pilar tersebut diharapkan dapat mewujudkan masyarakat Indonesia yang memiliki tingkat literasi keuangan yang tinggi sehingga masyarakat dapat memilih dan memanfaatkan produk jasa keuangan guna meningkatkan kesejahteraan (Otoritas Jasa Keuangan, 2015). Penelitian di India pada distrik Lunglei (Lalrinmawia dan Gupta,
2015) menunjukkan bahwa sebagian besar petani memiliki literasi keuangan yang rendah $(86,56 \%)$ dan hanya $4,06 \%$ yang memiliki literasi keuangan yang baik. Petani memiliki kecenderungan yang lebih baik dalam literasi keuangan ketika terkait dengan prinsip-prinsip keuangan yang umum saja. Bahkan, hasil dari penelitian (Mendari dan Kewal, 2013) terhadap mahasiswa menunjukkan bahwa dari semua aspek literasi keuangan, baik dari aspek pengetahuan keuangan pribadi, tabungan dan pinjaman, asuransi, dan investasi mengindikasikan literasi keuangan yang rendah walaupun melalui pendidikan disekolah sudah diberikan materi-materi perkuliahan yang berkaitan tentang aspek-aspek dalam literasi keuangan tersebut.

Penelitian sebelumnya Xiao et al., (2007) menyimpulkan bahwa cara terbaik untuk memperbaiki perilaku di usia dewasa adalah dengan cara mengajarkan perilaku yang baik sejak kecil, termasuk perilaku keuangan (financial behavior).

Widyawati (2012) mendapatkan jawaban yang sama yakni rendahnya nilai literasi setelah peneliti faktor literasi finasial mahasiswa. Literasi keuangan tidak bergantung sepenuhnya pada latar belakang pendidikan. Padahal, Lalrinmawia dan Gupta (2015) menyatakan bahwa yang paling sering melakukan kesalahan dalam pengambilan keputusan dalam hal keuangan adalah mereka yang kurang/tidak memiliki literasi keuangan. Hal ini senada dengan yang disampaikan Krishna et al. (2010) yang menjelaskan bahwa literasi keuangan membantu individu agar terhindar dari masalah keuangan. Kesulitan keuangan bukan hanya fungsi dari pendapatan semata (rendahnya pendapatan). Kesulitan keuangan juga dapat muncul jika terjadi kesalahan dalam pengelolaan keuangan (miss management) seperti kesalahan penggunaan kredit, dan tidak adanya perencanaan keuangan.

Beberapa penelitian menunjukkan bahwa literasi keuangan yang mencukupi akan memberikan pengaruh positif terhadap perilaku keuangan seseorang (Robb dan 
James, 2009). Lusardi dan Mitchell (2014) pun menyatakan apabila seseorang yang memiliki pengetahuan keuangan cenderung menggunakan pendapatannya untuk menabung dan sedikit untuk memenuhi kebutuhan konsumtif, sehingga dapat digunakan di masa depan ketika terjadi penurunan pendapatan, sehingga dapat dikatakan seseorang dengan literasi keuangan yang baik akan meningkatkan kemapanan finansial dan mengurangi masalah finansial di masa depan (Taft et al., 2013).

Jappelli dan Padula (dalam Lusardi dan Mitchell, 2014) menyatakan adanya hubungan yang signifikan antara literasi keuangan dan kesejahteraan dalam satu siklus waktu tertentu. Hal serupa diungkapkan oleh Behrman et al. (2012) bahwa literasi keuangan berhubungan positif dan signifikan terhadap kesejahteraan secara akumulatif berdasarkan beberapa komponen yang diteliti seperti sekolah, pengalaman kerja, dan latar belakang keluarga.

Bhushan dan Medury (2013) menjelaskan literasi keuangan menjadi semakin kompleks selama beberapa tahun terakhir dengan banyaknya produk keuangan baru. Kelompok yang menarik diperhatikan adalah masyarakat perpenghasilan rendah. Abdurachman et al. (2009) menyatakan bahwa pendapatan rendah dan tidak pasti yang diperoleh keluarga petani secara tidak langsung akan menimbulkan masalah dalam keluarganya. Salehin et al. (2009) melakukan penelitian untuk mengetahui apakah ada perbedaan yang signifikan antara komponen literasi keuangan di kalangan petani Kab. Tasikmalaya dan Garut.

Penelitian Ravikumar et al. (2013) yang meneliti 100 orang petani melati India di distrik Erode dan 100 petani melati di distrik Madurai menunjukkan bahwa petani yang telah diberi pelatihan dan informasi tentang pengelolaan keuangan memiliki literasi keuangan pertanian yang lebih baik. Penelitian yang dilakukan Shen et al. (2015) terkait literasi keuangan dan konflik keuangan, menemukan bahwa ketika pembelian produk dan jasa keuangan mengarah kemasalah keuangan, orang dengan literasi keuangan yang lebih tinggi secara agresif akan menangani masalah tersebut. BucherKoenen dan Lusardi (2011) dalam penelitiannya di Jerman, membandingkan tingkat literasi keuangan Jerman timur dan Jerman barat dimana terdapat perbedaan signifikan antara responden di kedua tempat tersebut.

\section{METODE PENELITIAN}

Sesuai dengan tujuan penelitian dimana informasi ini akan digunakan untuk merepresentasikan kondisi beberapa sentra pertanian di Indonesia khususnya pulau Jawa secara umum, maka pemilihan wilayah survei untuk melakukan pengambilan data ditetapkan di 3 Provinsi yakni meliputi Jawa Barat, Jawa Tengah dan Jawa Timur pada periode tahun 2017. Pada tabel 1 disajikan jumlah sampel dan sebaran responden.

Tabel 1

Sebaran wilayah survei dan jumlah sampel

\begin{tabular}{cll}
\hline \hline No & \multicolumn{1}{c}{ Propinsi } & \multicolumn{1}{c}{ Kabupaten } \\
\hline 1 & Jawa Barat & Pengalengan \\
2 & Jawa Tengah & Wonosobo \\
3 & Jawa Timur & Batu \\
\hline Sumber: Data Tahun 2017 diolah &
\end{tabular}

Jumlah sampel keseluruhan yang akan dijadikan sebagai sumber informasi dalam penelitian ini ditentukan menggunakan kaidah Slovin yang merupakan turunan dari penentuan sampel dengan pendekatan sebaran normal sebagai berikut: 
$n=\left(\frac{Z_{\alpha / 2}}{e}\right)^{2} p(1-p)$ dengan faktor populasi

terhingga $n^{*}=\frac{n}{1+\frac{n-1}{N}}$

Dimana:

a : Tingkat kepercayaan

e : simpangan dugaan parameter

$Z_{\alpha / 2} \quad$ : nilai sebaran normal

$\mathrm{P} \quad$ : Proporsi populasi dengan sifat tertentu

N : Jumlah Populasi

$\mathrm{n} \quad$ : Jumlah sampel populasi tak hingga

$\mathrm{n}^{*} \quad$ : Jumlah sampel terkoreksi populasi terhingga

Dengan mengasumsikan populasi menyebar normal dan tingkat kepercayaan 95\%, serta proporsi populasi yang memiliki ciri tertentu adalah $50 \%(p=0,5)$, maka formula jumlah sampel terkoreksi dapat ditulis ulang menjadi $n^{*}=\frac{N}{e^{2} N+1}$. Berdasarkan formula terakhir ini kemudian dengan menetapkan simpangan dugaan (e) sebesar 7,5\%, maka jumlah sampel petani keseluruhan adalah 180 responden dimana populasi responden adalah petani dengan luas lahan antara 0,25 hingga 1,00 Ha yang belum memiliki akses (tabungan) pada lembaga keuangan formal.

Setelah jumlah sampel keseluruhan diperoleh, tahap berikutnya adalah menetapkan sebarannya pada masing-masing wilayah. Untuk keperluan ini digunakan pendekatan azas proporsional berdasarkan jumlah petani, sehingga diperoleh hasil seperti disajikan pada Tabel 2.

Tabel 2

Jumlah dan sebaran sampel

\begin{tabular}{|c|c|c|c|c|c|c|}
\hline \multirow{2}{*}{ No } & \multirow{2}{*}{ Propinsi } & \multirow{2}{*}{ Kabupaten } & \multicolumn{3}{|c|}{ Petani dengan Luas Lahan (Ha) } & \multirow{2}{*}{ Jumlah } \\
\hline & & & $<0,5$ & $0,5-0,75$ & $0,75-1,00$ & \\
\hline 1 & Jawa Barat & Pengalengan & 15 & 30 & 15 & 60 \\
\hline 2 & Jawa Tengah & Wonosobo & 15 & 30 & 15 & 60 \\
\hline \multirow[t]{2}{*}{3} & Jawa Timur & Batu & 15 & 30 & 15 & 60 \\
\hline & & Jumlah & 45 & 90 & 45 & 180 \\
\hline
\end{tabular}

Sumber: Data Th.2017 diolah

Dalam penelitian ini unit analisisnya adalah individu atau anggota masyarakat, dimana dalam pemilihannya menggunakan basis rumah tangga. Teknik sampling yang akan digunakan adalah multistage random sampling. Dari setiap kabupaten akan dipilih 2 kecamatan secara cluster random sampling, kemudian dari setiap kecamatan akan di ambil 2 kelurahan dengan metode yang sama.

Demikian juga dari masing-masing Kecamatan terpilih akan diambil 2 RW /Dusun. Tahap terakhir adalah pemilihan petani yang didasarkan atas luas lahan, dimana luas lahan ini akan dijadikan sebagai strata. Kemudian dari masing-masing strata ini akan diambil secara acak petani secara proporsional sesuai dengan jumlah petani pada masing-masing strata luas lahan.

Data yang digunakan dalam penelitian ini terdiri dari data primer dan data sekunder. Data primer dalam penelitian ini berupa informasi terkait pengetahuan dan keikutsertaan dengan lembaga keuangan yang terdapat di daerah sekitar responden tinggal, maupun pengetahuan terkait lembaga keuangan secara umum. Kegiatan yang dilakukan untuk memperoleh data primer adalah melalui wawancara tatap muka (indepth interview) kepada petani terpilih. Kemudian untuk melengkapi data primer akan dilakukan pengumpulan informasi dari sumber lain (data sekunder) dari hasil penelitian yang dipergunakan dalam tahap 
persiapan. Data sekunder ini diperoleh dari Kementerian, lembaga terkait, lembaga keuangan, dan lembaga penyelenggara sistem pembayaran.

\section{ANALISIS DAN PEMBAHASAN}

Berdasarkan informasi sebelumnya terlihat bahwa bertani merupakan pekerjaan utama, walaupun sebagian petani memiliki pekerjaan lain. Berdasarkan diagram pada Gambar 1 dapat terlihat bahwa sebagian besar petani $(100 \%)$ sumber utama pendapatannya adalah dari hasil pertanian. Sebagian lainnya memperoleh pendapat dari menjual hasil ternak (17\%) dan pekerja informal/buruh (17\%), dan wirausaha $(11 \%)$. Dengan persentase kecil $<10 \%$ petani juga memiliki sumber pendapatan dari pasangan suami/istri, bekerja di instansi pemerintah atau mendapatkan bantuan dari keluarga/kerabat. Berdasarkan diagram pada Gambar 1 menunjukkan bahwa memang sumber pendapatan utama petani hortikultura adalah dari hasil pertaniannya, bukan dari sumber lainnya.

Berdasarkan informasi tersebut dapat dipastikan bahwa pendapatan petani sangat tergantung dari hasil panennya. Apabila hasil panennya baik dan harga jual sedang normal atau tinggi, maka petani berpeluang mendapatkan keuntungan dari hasil usahanya. Akan tetapi kemungkinan terjadi hal yang sebaliknya juga ada, dimana hasil panen petani kurang baik (jumlah panen sedikit) maka akan berdampak pada turunnya pendapatan petani bahkan bisa merugi. Dampak dari kondisi ini adalah petani mengalami kesulitan memperoleh modal untuk aktivitas usaha tani berikutnya. Untuk mengatasi hal ini tidak jarang petani meminjam uang kepada pihak lain sebagai modal usahatani.

Hasil Pertanian/perkebunan milik sendiri

Pekerja formal/Pegawai Swasta

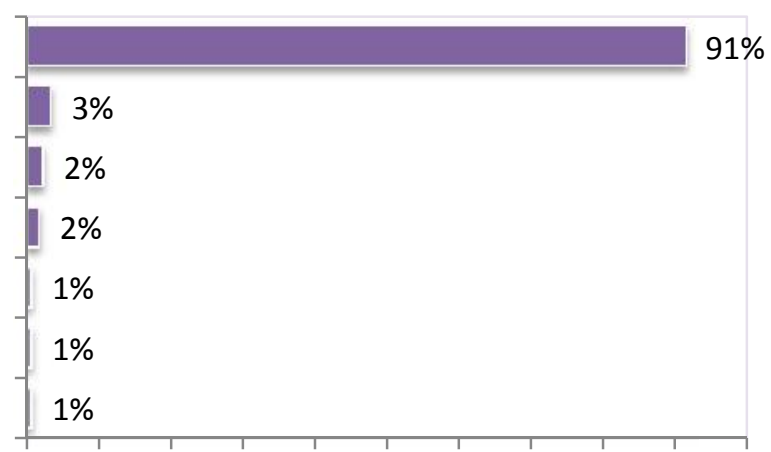

Pekerja informal/Buruh

Pasangan (suami/istri)

Wiraswasta/Wirausaha

Jual beli hasil ternak atau panen

Bekerja di Instansi Pemerintah

$0 \% \quad 10 \% \quad 20 \%$ 30\% 40\% 50\% 60\% 70\% 80\% 90\% $100 \%$

\section{Gambar 1}

Sumber: Data Th..2017 diolah

\section{Sumber pendapatan utama}

Pendapatan petani hortikultura cukup bervariasi, hal ini berkaitan dengan luas lahan dan jenis tanaman yang diusahakan. Disamping itu terdapat juga faktor eksternal yakni jumlah hasil panen yang diperoleh. serta harga jual saat panen apakah sedang tinggi atau rendah. Terlihat bahwa pendapatan petani bervariasi, adapun jumlah petani yang memperoleh pendapatan dengan jumlah > Rp. 5.000 .000 cukup banyak (26\%) kemudian sebanyak (19\%) petani memperoleh pendapatan Rp. 1.750.001 - Rp. 2.500.000, kemudian tidak jauh berbeda (18\%) petani memperoleh pendapatan $\mathrm{Rp}$. 2.500.001 - Rp. 3.000.000, diikuti dengan (14\%) petani memperoleh pendapatan Rp. 4.500.001 - Rp. 5.000.000.

Hal tersebut menandakan bahwa cukup banyak petani yang sebenarnya memperoleh pendapatan per bulan dengan jumlah yang cukup banyak, bahkan dengan pendapatan tersebut petani ada yang dapat mengguna- 
kan jasa lembaga keuangan untuk menyimpan uangnya. Peluang inilah yang mungkin dapat dilihat oleh lembaga keuangan agar dapat memperluas jangkauan pasar, tentunya dengan pengenalan yang komunikatif dan membangun kepercayaan yang baik dengan petani, agar mereka yakin, tertarik untuk menggunakan dan tentunya dengan tidak mempersulit syaratnya.

Beberapa petani lainnya dengan persentase yang relatif kecil $(<10 \%)$ memiliki pendapatan yang beragam mulai dari Rp.600.000-Rp.4.500.000, akan tetapi yang mengejutkan masih terdapat petani yang memperoleh pendapatan perbulannya hanya sebesar $<=$ Rp. 600.000. terdapat kemungkinan bahwa petani tersebut hanyalah petani penggarap, sewa lahan, menanam komoditi dengan harga jual rendah atau memang karena kondisi ekonomi saat ini yang cenderung membuat harga jual komoditi berfluktuasi.

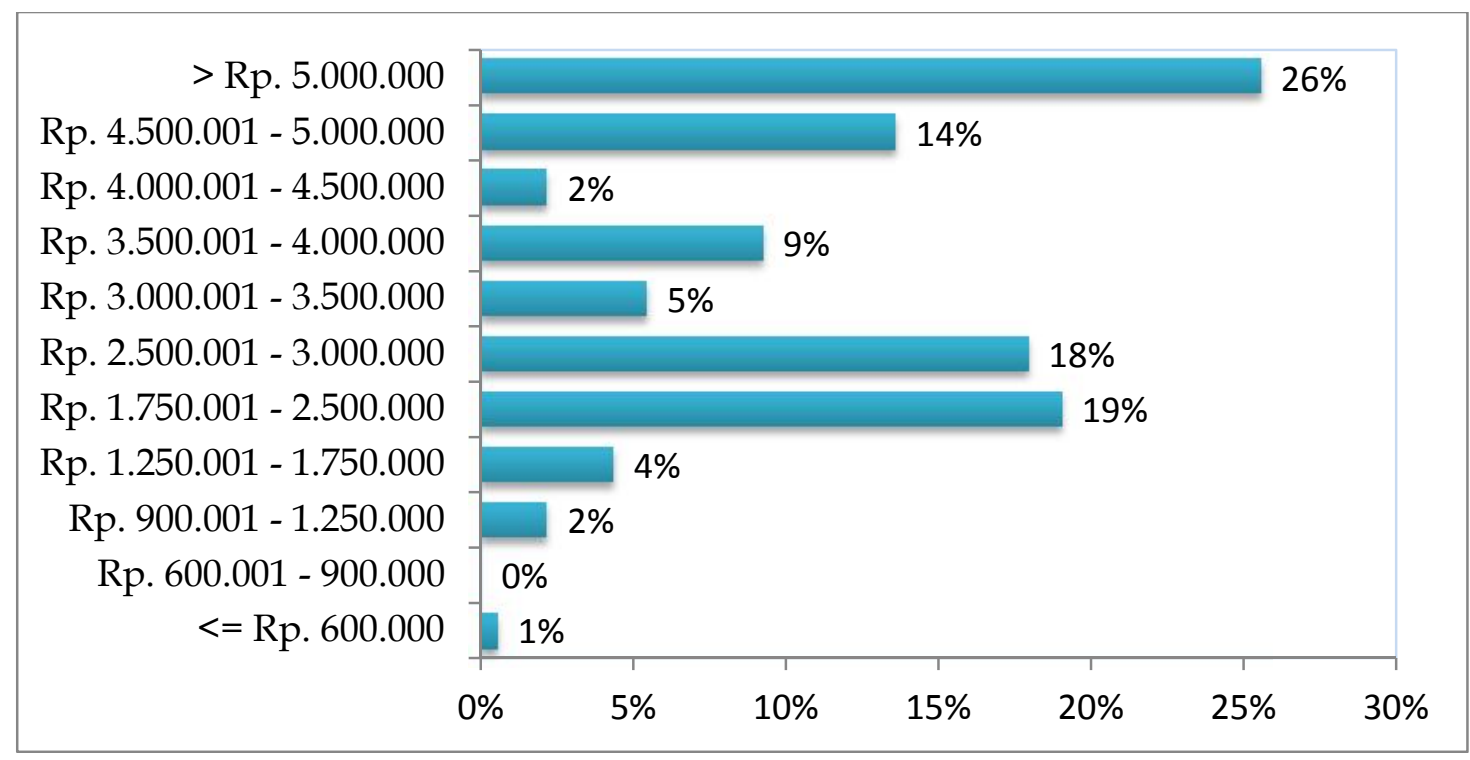

Sumber: Data Th.2017 diolah

Gambar 2

Rata-rata pendapatan Petani Per Bulan

Penjabaran terkait rata-rata pengeluaran petani hortikultura dalam sebulan terdapat pada Gambar 3. Berdasarkan Gambar tersebut dapat dijabarkan bahwa jumlah petani yang memiliki pengeluaran per bulannya > Rp. 5000.000 hanya sedikit yakni $(1,09 \%)$, hal tersebut menandakan bahwa walaupun cukup banyak petani yang berpendapatan > Rp. 5.000.000 tetapi rata-rata hanya menggunakan untuk kebutuhan hidup perbulannya dengan nominal yang tidak banyak. Sehingga menunjukkan bahwa masih ada sebagian uang yang diperoleh petani tetapi tidak dikeluarkan, uang tersebut sebenarnya dapat ditabung atau disimpan di lembaga keuangan seperti perbankan, koperasi simpan pinjam atau lainnya, akan tetapi pada kenyataannya sebagian petani juga lebih memilih menginvestasikannya, seperti membeli lahan baru, kendaraan, rumah atau hal lainnya. Hal ini juga merupakan peluang yang dapat dimanfaatkan oleh para pelaku lembaga keuangan agar dapat menyerap uang yang tidak digunakan oleh petani untuk memenuhi kebutuhan hidupnya perbulan, atau jika petani mengajukan pinjaman kredit untuk memperbesar usahanya juga merupakan peluang, karena terlihat adanya kemampuan petani dalam melakukan pembayaran terhadap pinjamannya.

Sebagian besar petani memiliki pengeluaran perbulannya sebesar Rp. 1.750 .000 Rp. $2.500 .000 \quad(29,35 \%)$, diikuti dengan persentase yang hampir sama sebesar $\mathrm{Rp}$ 
1.250 .000 - Rp $1.750 .000(20,65 \%)$ dan Rp 2.500.000 - Rp 3.000.000. Hal ini searah dengan besaran pendapatan petani yang juga banyak dengan kisaran nominal tersebut. Hal yang menarik terlihat pada masih terdapatnya petani yang hanya memiliki pengeluaran perbulannya sebesar Rp.
600.000 - Rp. 900.000 (2,75\%), hal ini dimungkinkan sesuai dengan jumlah petani yang memiliki pendapat mendekati nominal tersebut.

Seorang petani tidak hanya mengeluarkan uang untuk kebutuhan rumah tangga, tetapi juga terdapat pengeluaran uang untuk

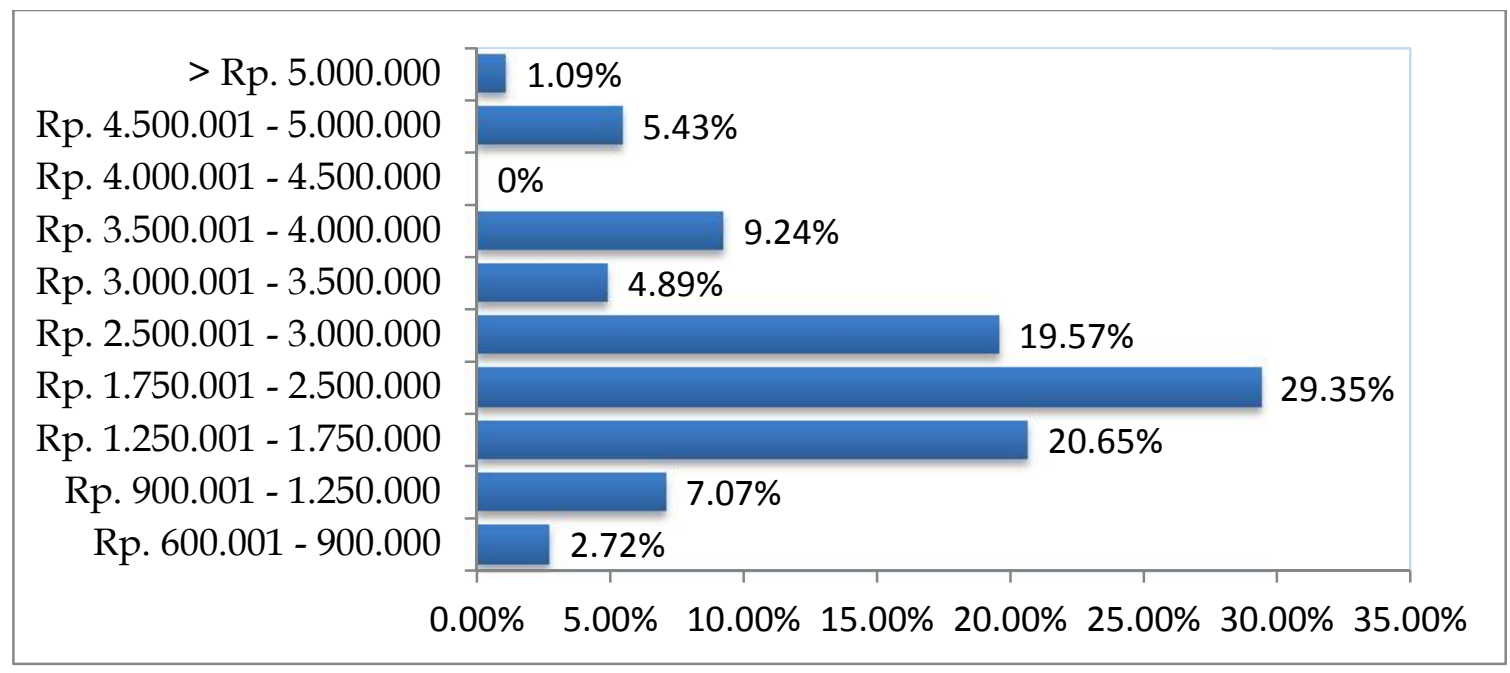

Sumber: Data Th.2017 diolah

kebutuhan pribadinya seperti kebutuhan membeli rokok, pakaian, atau hiburan. Petani rata-rata tidak mengeluarkan uang dengan nominal besar untuk keperluan pribadinya. Adapun besaran nilai yang dikeluarkan sebagian besar (64\%) kurang dari Rp.600.000 per bulan.
Sementara itu $20 \%$ petani memiliki pengeluaran antara Rp. 600.001 - 900.000 per bulan. Terdapat juga sebagian petani memiliki pengeluaran diatas 900.000, namun jumlahnya tidak besar. Secara rinci pengeluaran pribadi petani dijabarkan pada Gambar 4.

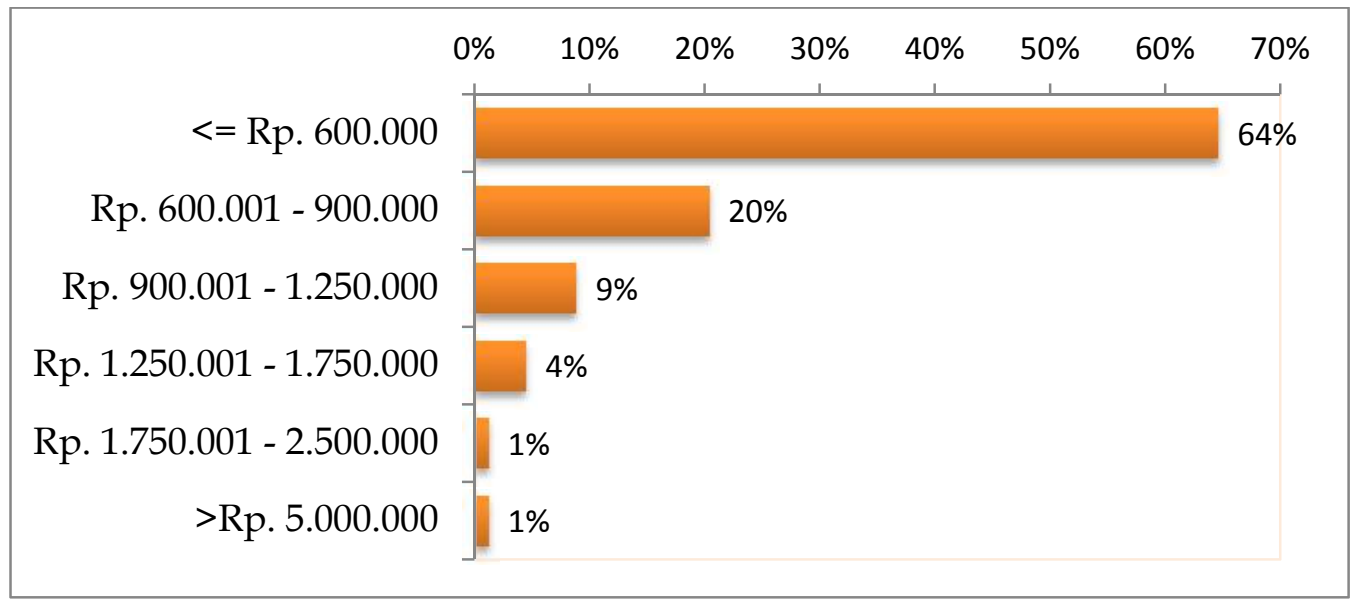

Gambar 4

Rata-rata pengeluaran pribadi

Sumber: Data Th.2017 diolah 
Selain pengeluaran rumah tangga dan pengeluaran pribadi, pengeluara lain yang juga diamati adalah pengeluaran melalui lembaga keuangan seperti tagihan listrik, air atau telepon, juga untuk pembayaran premi BPJS, angsuran kendaraan motor atau barang elektronik, juga membayar premi asuransi. Pada Gambar 5 disajikan informasi besarnya pengeluaran melalui lembaga keuangan. Dari gambar tersebut terlihat bahwa $71 \%$ petani memiliki pengeluaran tidak lebih dari $\mathrm{Rp}$ 600.000. Walaupun dengan nominal yang tidak terlalu besar, tetapi terlihat bahwa cukup banyak petani yang sudah ikut serta dengan lembaga keuangan, dan hal tersebut merupakan peluang bagi lembaga keuangan untuk dapat melebarkan jangkauan pasar.

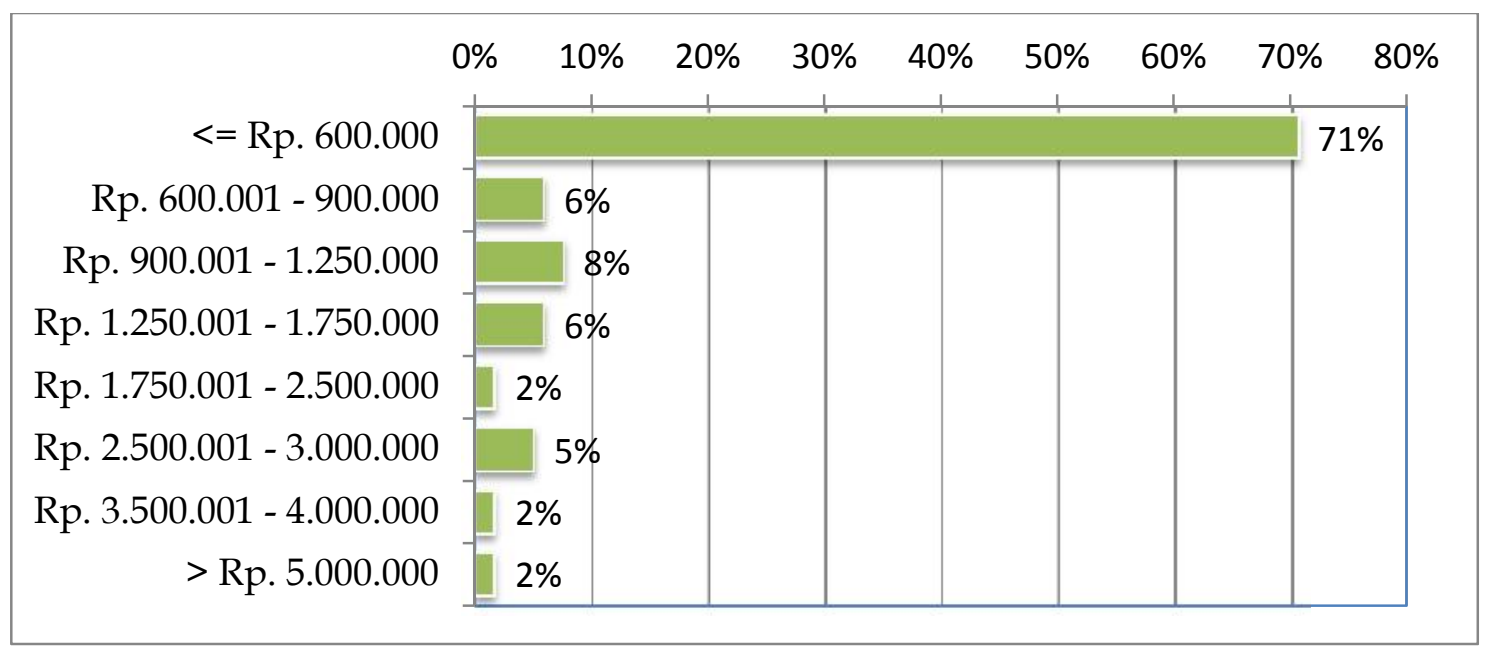

Gambar 5

Sumber: Data Th.2017 diolah

Rata-rata pengeluaran terkait dengan lembaga keuangan

\section{Perencanaan Penggunaan Pendapatan Petani}

Pendapatan yang diperoleh petani tidaklah rutin setiap bulan, namun lebih bersifat musiman sesuai dengan pola panen dari komiditas yang ditanam, oleh karena itu penting bagi petani untuk membuat perencanaan pengelolaan keuangan perbulannya, agar pendapatannya dapat terbagi rata untuk kebutuhan hidup dalam kurun waktu tertentu.

Berdasarkan informasi yang tersaji pada Gambar 5, terlihat bahwa sebanyak 43\% petani selalu merencanakan keuangannya kedepan, sebagian lainnya sebesar 34\% petani kadang-kadang saja atau tidak rutin melakukan perencanaan keuangan kedepannya, dan sebagian lainnya sebesar 23\% tidak melakukan perencanaan. Bagaimana sifat perencanaan keuangan yang dilakukan oleh petani, apakah rinci atau hanya secara umum saja. Pada Gambar 6 disajikan informasi mengenai sifat perencanaan keuangan petani.

Sebagian petani yang membuat perencanaan keuangan hanya membuatnya secara umum $(87 \%)$ dan sebagian kecil lainnya (13\%) justru sudah mulai membuat perencanaan keuangan secara terinci. Berdasarkan fakta ini tidak lebih dari $6 \%$ petani yang sudah melakukan perencanaan keuangan secara rutin dan rinci. Sementara sebagian besar lainnya sudah mulai membuat perencanaan walau baru sebatas garis besarnya saja dan sebagian lainnya tidak melakukan perencanaan sama sekali.

Perencanaan keuangan merupakan aktivitas yang perlu dibiasakan mengingat manfaatnya sangat besar dalam meningkatkan nilai uang. Melalui perencanaan, penggunaan uang menjadi lebih terarah, apalagi jika jumlahnya terbatas. Sebaliknya peng- 
gunaan uang tanpa terencana akan cenderung melakukan pengeluaran yang tidak terkontrol.

Fakta menarik terkait dengan perencanaan keuangan dan sifat perencanaannya adalah konsistensi untuk melaksanakannya. Tidak jarang ditemui bahwa sesorang melakukan perencanaan dengan baik namun lemah atau tidak disiplin dalam pelaksanaannya. Pada Gambar 6 dipaparkan pelaksanaan atas rencana keuangan yang telah dilakukan oleh petani. Sejumlah $27 \%$ petani yang mengimplementasikan rencana tersebut secara keseluruhan. Bahkan mayoritas petani $(72 \%)$ hanya mengimplementasikan sebagian saja. Sisanya sama sekali tidak melaksanakan.

\section{Pengelolaan Keuangan Petani}

Pengelolaan keuangan tidak saja diperlukan untuk mengatur cash-flow rumah tangga, namun juga diperlukan untuk mengelola atas kelebihan dana yang dimiliki. Dimana kelebihan dana ini merupakan selisih antara pendapatan dengan seluruh biaya pokok atau biaya rutin yang dikeluarkan per bulannya.

Terdapat $24 \%$ petani selalu memiliki kelebihan dana, sementara mayoritas petani
(68\%) hanya kadang-kadang saja memiliki kelebihan dana, sedangkan $8 \%$ tidak pernah memiliki kelebihan dana. Informasi ini menunjukkan bahwa petani hortikultur sebagian besar memiliki keuntungan atas usaha tani yang dilakukannya, informasi yang menarik untuk ditelusuri adalah bagaimana petani mengelola kelebihan keuangannya tersebut.

Pada Gambar 6 memaparkan hasil penelusuran terhadap aktivitas petani dalam mengelola kelebihan dananya, terlihat bahwa hampir setengah dari petani $(49 \%)$ yang memiliki kelebihan dana menyimpannya dengan cara ditabung di lembaga keuangan, namun demikian terdapat $9 \%$ petani menyimpan uang sisanya dirumah. Sebanyak $21 \%$ petani membelanjakan sisa uangnya dan sebagian lagi diinvestasikan. Informasi ini jelas semakin memperkuat bahwa penting adanya perluasan jangkauan lembaga keuangan karena cukup berpotensi petani menjadi nasabahnya.

Mengingat pendapatan petani tidak rutin setiap bulannya, sementara kebutuhan yang harus ditutupi bersifat rutin bahkan harian, maka tidak menutup kemungkinan bahwa ada petani yang pernah mengalmi kekurangan uang.

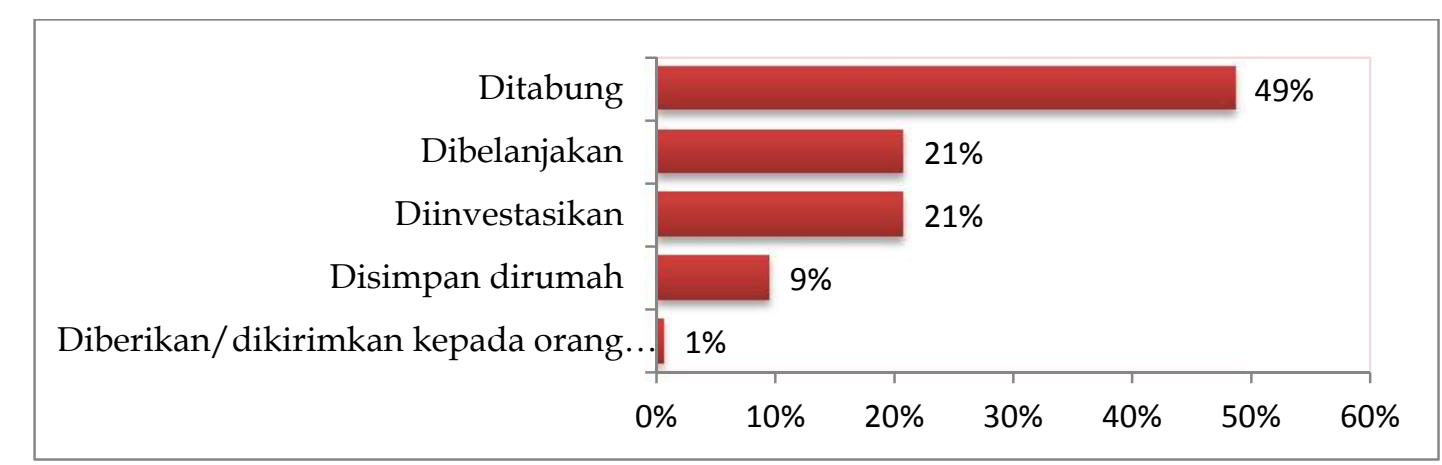

\section{Gambar 6 \\ Penggunaan sisa uang}

Sumber: Data Th.2017 diolah

Jika hal ini terjadi tindakan apa yang dilakukan oleh petani untuk menutupi kebutuhan pokoknya. Terdapat $38 \%$ petani terkadang mengalami kekurangan uang untuk memenuhi kebutuhan rutinnya, namun terdapat $12 \%$ petani yang menyatakan sering mengalami kekurangan. uang dan bahkan 5\% menyatakan selalu mengalami kekurangan uang. Petani yang sering dan selalu mengalami kekurangan 
uang umumnya disebabkan oleh pendapatannya yang tidak mencukupi untuk menutupi kebutuhan pokok. Hal ini disebabkan lahan yang dimilikinya tidak terlalu luas, sehingga hasil panennya tidak mampu menutupi kebutuhan selama beberapa bulan kedepan. Sementara itu bagi petani yang kadang-kadang mengalami kekurangan uang dapat disebabkan gagal panen yang disebabkan baik oleh hama penyakit atau kondisi cuaca. Kemungkinan lain yang dapat menurunkan pendapatan petani adalah harga jual komoditi yang ditanamnya sedang turun karena panen raya. Dalam kondisi kekurangan uang, petani umumnya akan meminjam pada pihak lain baik untuk keperluan konsumtif maupun modal kerja. Dalam kondisi seperti ini kehadiran lembaga keuangan saat krusial, namun demikian karena aspek ketaklayakan baik dari sisi skala usaha maupun dari sisi agunan, petani cenderung akan meminjam ke perorangan "rentenir" karena syaratnya mudah dan prosesnya cepat, meski bunga pinjamannya sangat tinggi.

Disamping alasan yang telah dikemukakan terdahulu, alasan lain petani kekurangan dana disajikan pada Gambar 7. Dimana pada gambar tersebut terlihat bahwa alasan petani mengalami kekurangan uang untuk memenuhi kebutuhan rutin/pokoknya adalah karena penghasilannya yang tidak menentu (58\%), kemudian dengan jumlah yang tidak jauh bebeda yakni $57 \%$ menyatakan adanya pengeluaran tak terduga. Alasan terakhir ini dapat disebabkan karena petani tidak merencanakan pengelolaan keuangannya, atau memang karena ada kebutuhan mendesak lainnya seperti: anggota keluarga sakit atau ada acara hajatan dan lain sebagainya.

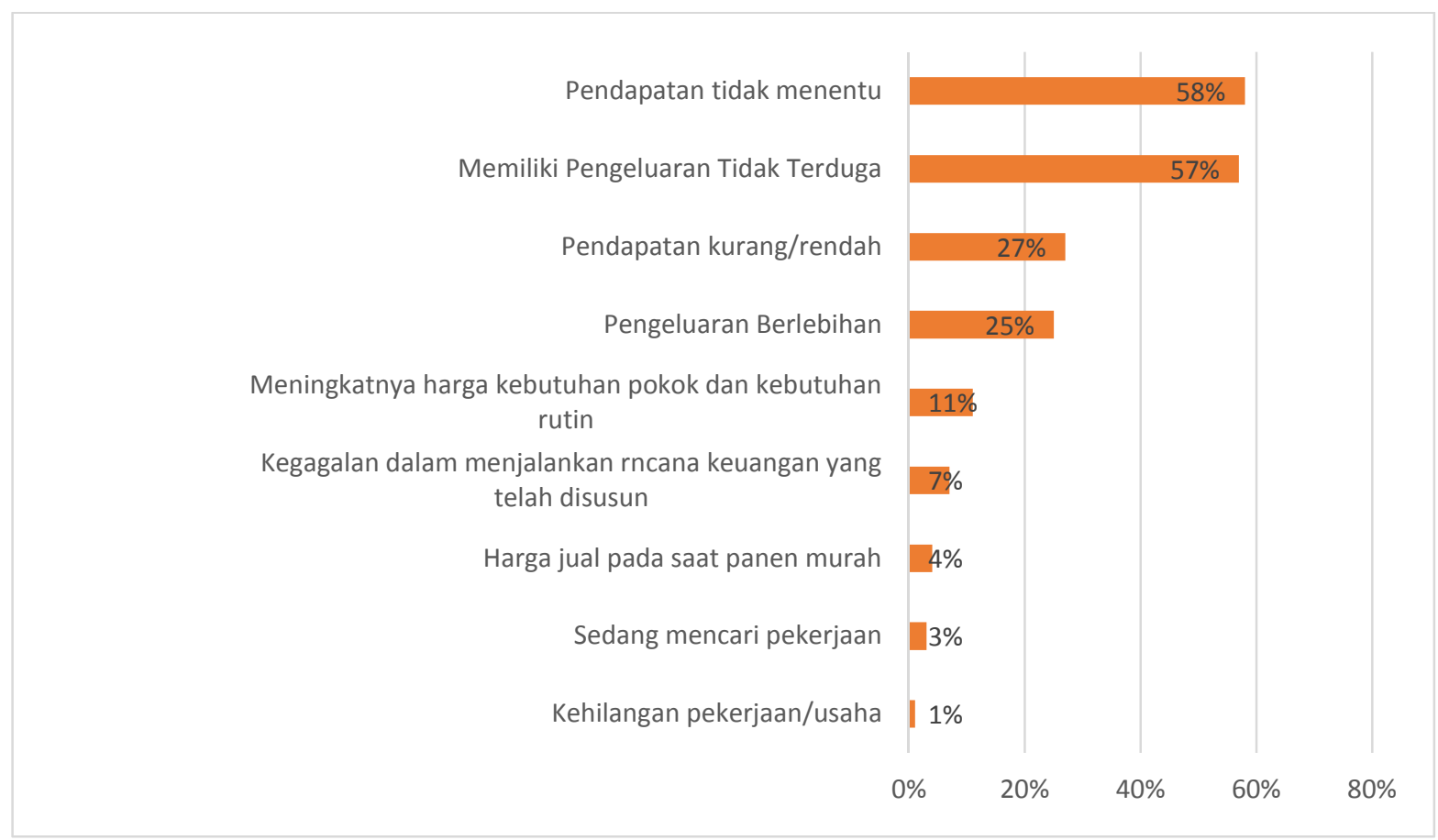

Sumber: Data Th.2017 diolah

\section{Gambar 7}

\section{Alasan sampai kekurangan uang}

Gambar 8 terlihat bahwa petani yang sedang mengalami kekurangan uang untuk memenuhi kebutuhan rutin/pokoknya cenderung akan meminjam kepada keluarga/ teman $(87 \%)$, hal ini mungkin disebabkan karena masih kurangnya pengetahuan terkait adanya lembaga keuangan, atau kurangnya jangkauan lembaga keuangan kebebe- 
rapa daerah tersebut, atau bahkan dapat juga dikarenakan persyaratan dan prosedur yang dianggap merepotkan bagi petani. Sementara itu $14 \%$ petani akan menggunakan tabungannya untuk memenuhi kebutuhan pokoknya. Hal menarik dari kasus kekurangan uang, $12 \%$ petani menyatakan meminjam pada bank/lembaga keuangan. Informasi ini menunjukkan bahwa masih sangat kecil jumlah petani yang mengandalkan lembaga keuangan untuk melakukan peminjaman, sedangkan $10 \%$ petani lebih memilih untuk menjual barang/asset yang dimiliknya. Hasil ini menunjukkan penting menjadi perhatian oleh lembaga keuangan bahwa masih terdapat peluang di beberapa daerah, khususnya daerah pertanian di pulau Jawa.

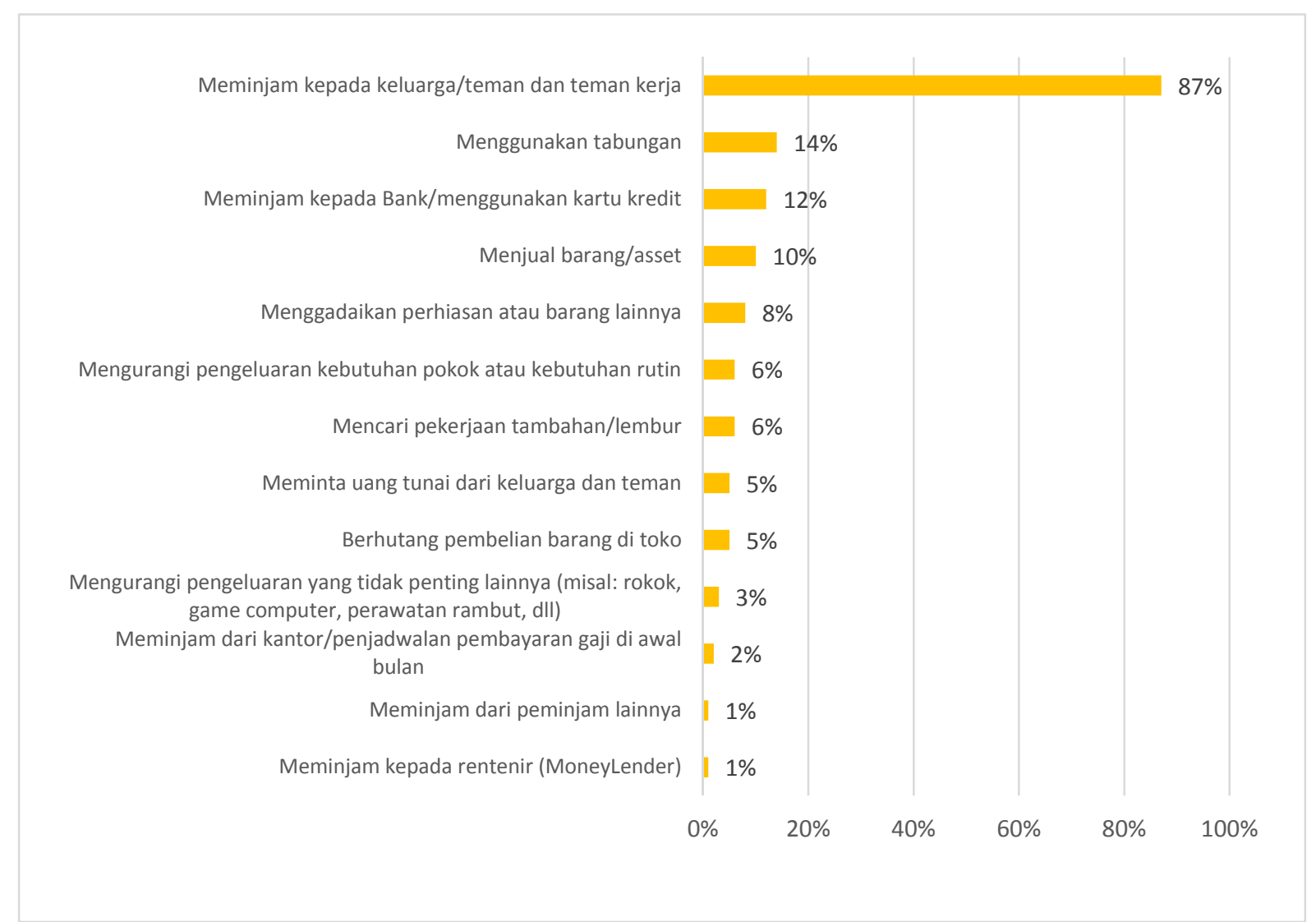

Sumber: Data Th.2017 diolah

\section{Gambar 8}

Tindakan yang dilakukan petani saat kekurangan uang

\section{Pendapatan dan Pengeluaran}

Untuk mengetahui perilaku petani dalam mengatasi permasalahan terkait dengan kebutuhan dana dalam jumlah besar, telah dilakukan penggalian informasi terkait hal tersebut dengan cara menanyakan apakah dalam 12 bulan ke depan akan ada pe- ngeluaran dalam jumlah besar yang nilainya/jumlahnya paling tidaksama dengan pendapatan setiap bulannya. Bahwa 55\% petani memiliki pengeluaran dalam jumlah besar yang nilainya paling tidak sama dengan pendapatan, sedangkan $45 \%$ petani menyatakan tidak memiliki . 


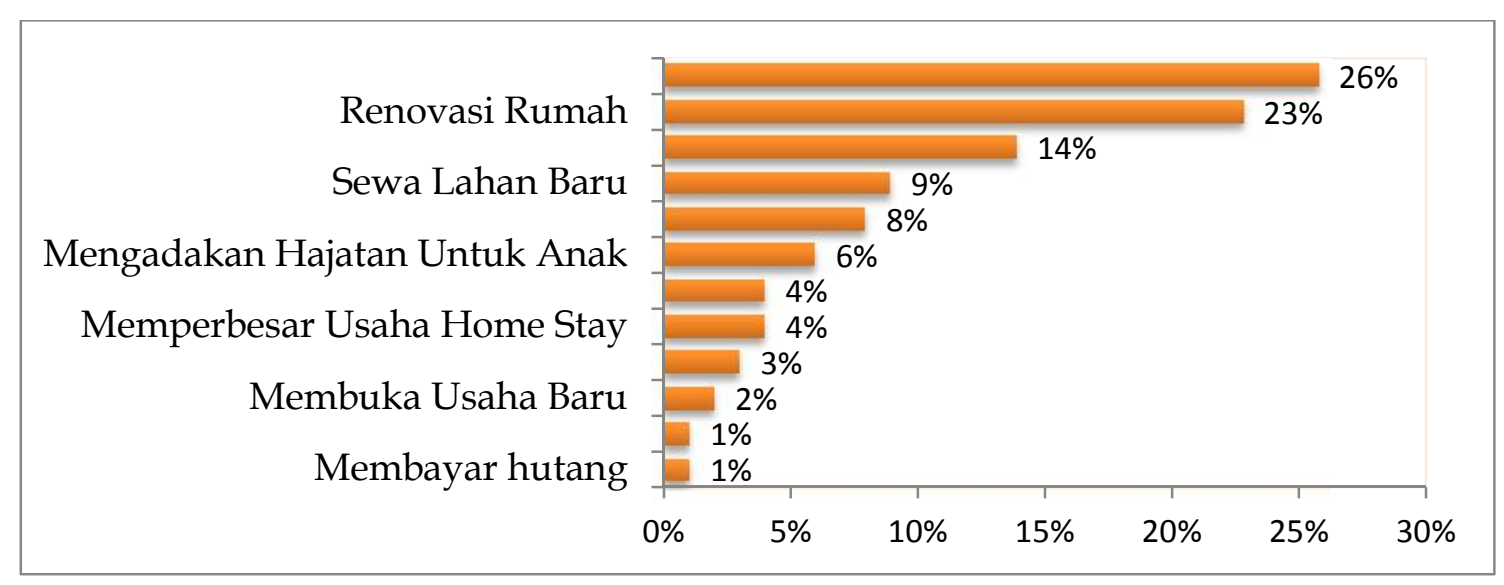

Gambar 9

Sumber: Data Th.2017 diolah

Jenis pengeluaran yang telah direncanakan

Berdasarkan Gambar 9, 26\% petani akan mengeluarkan biaya yang relatif besar dan sudah direncanakan untuk pendidikan anak, sebanyak $23 \%$ petani merencanakan merenovasi rumah, $14 \%$ untuk modal membeli bibit tanaman, 9\% petani akan sewa lahan baru, dan sebanyak $8 \%$ untuk acara pernikahan serta $6 \%$ untuk mengadakan hajatan anak, sedangkan sisanya untuk berangkat haji, memperbesar usaha beli kendaraan bermotor, membuka usaha baru, membuat gudang produksi dan membayar hutang.

\section{Penurunan Pendapatan Tak Terduga}

Dalam setahun terakhir, responden pernah mengalami penurunan pendapatan tak terduga yang nilainya/jumlahnya paling tidak sama dengan pendapatan responden setiap bulan. Sebagian besar responden yaitu $71 \%$ mengalami penurunan pendapatan tak terduga yang nilainya/jumlahnya paling tidak sama dengan pendapatan sedangkan sisanya $35 \%$ tidak pernah mengalami penurunan pendapatan tak terduga yang nilainya/jumlahnya paling tidak sama dengan pendapatan.

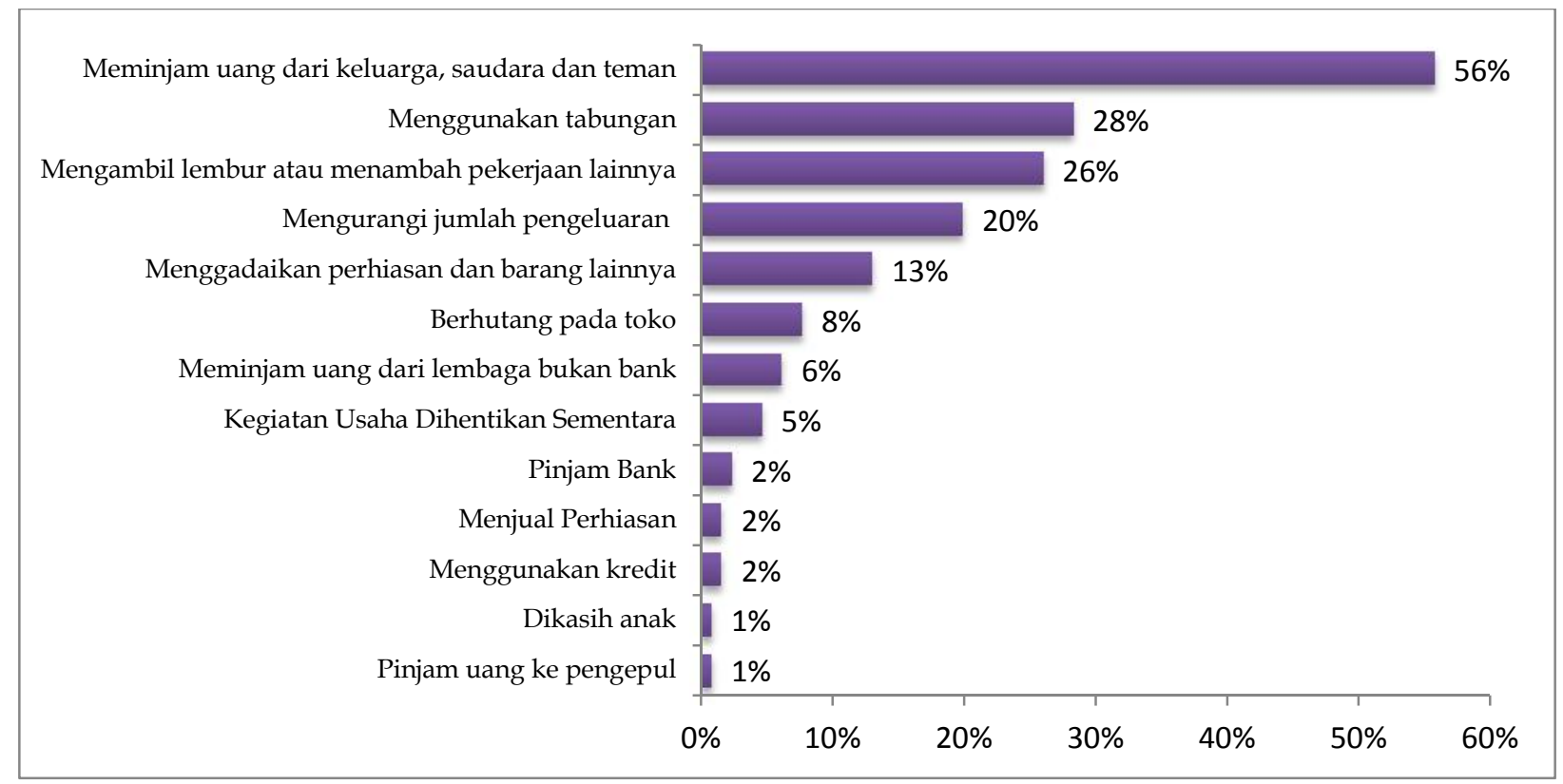

Gambar 10 
Sebagian besar responden sebanyak 56\% akan meminjam kepada keluarga atau teman jika suatu saat penghasilan tiba-tiba menurun, sebanyak $28 \%$ akan menggunakan tabungan, $26 \%$ responden akan lembur atau menambah pekerjaan, $20 \%$ akan mengurangi pekerjaan, $13 \%$ akan menggadaikan perhiasan atau barang lain.

\section{Perencanaan Di Masa Tua}

Berdasarkan gambar 11 di bawah, sebagian besar responden sebanyak 58\% memiliki rencana akan selalu bekerja dan menabung untuk menutupi pengeluaran dimasa tua. Sebanyak $24 \%$ responden memiliki rencana mencari penghasilan tambahan atau usaha, $15 \%$ berencana menjual aset, $7 \%$ responden berencana meminta bantuan keuangan dari keluarga, 6\% berencana menggunakan aset keuangan lainnya. Dan sisanya dalah minta kepada anak, investasi tanah $(2 \%)$, asuransi $(1 \%)$, mempersiapkan anak menjalankan usaha (1\%), memperbanyak relasi dan menggunakan dana pensiun (1\%).

Berdasarkan gambar 12 dari rencana tersebut mana saja yang sudah dilaksanakan, responden sebagian besar menjawab sebanyak $49 \%$ akan selalu bekerja dan menabung $(47 \%)$, sedangkan $10 \%$ mencari penghasilan tambahan atau usaha, sedangkan dibawah 2\% adalah minta kepada anak, menjual aset, menyewakan lahan, mempersiapkan menjalankan usaha, investasi tanah, mengharapkan dapat warisan dan asuransi. Sebagian besar responden sebesar 79\% berpendapat bahwa strategi tersebut cukup menutupi pengeluaran di masa tua, sedangkan $21 \%$ merasa belum cukup menutupi pengeluaran di masa tua. Sebagian besar responden sebesar 97\% tidak mengikuti program pensiun di tempat kerja atau DPLK, sedangkan 3\% mengikuti program pensiun di tempat kerja atau DPLK.

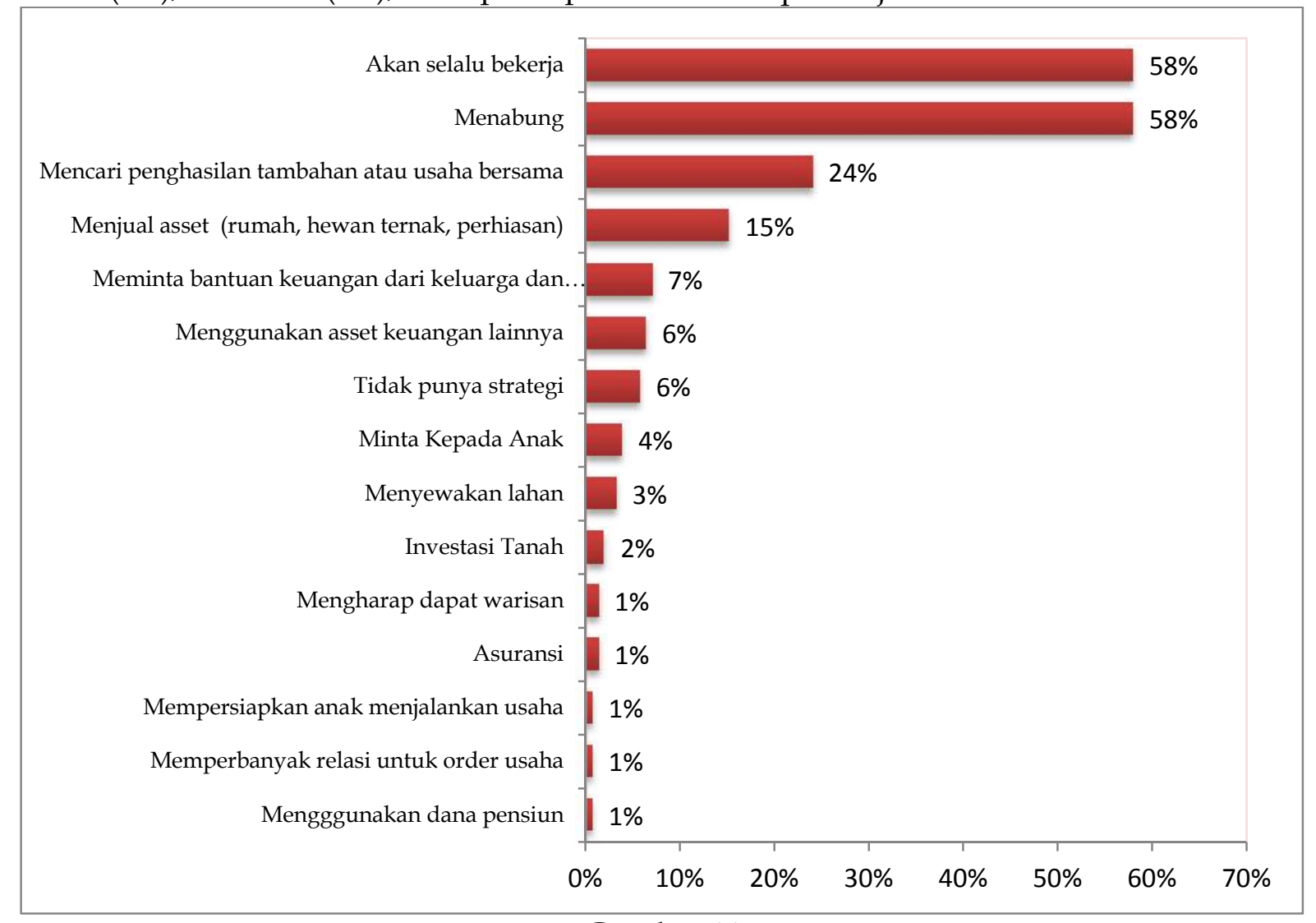

Sumber: Data diolah

\section{Rencana untuk menutupi pengeluaran}




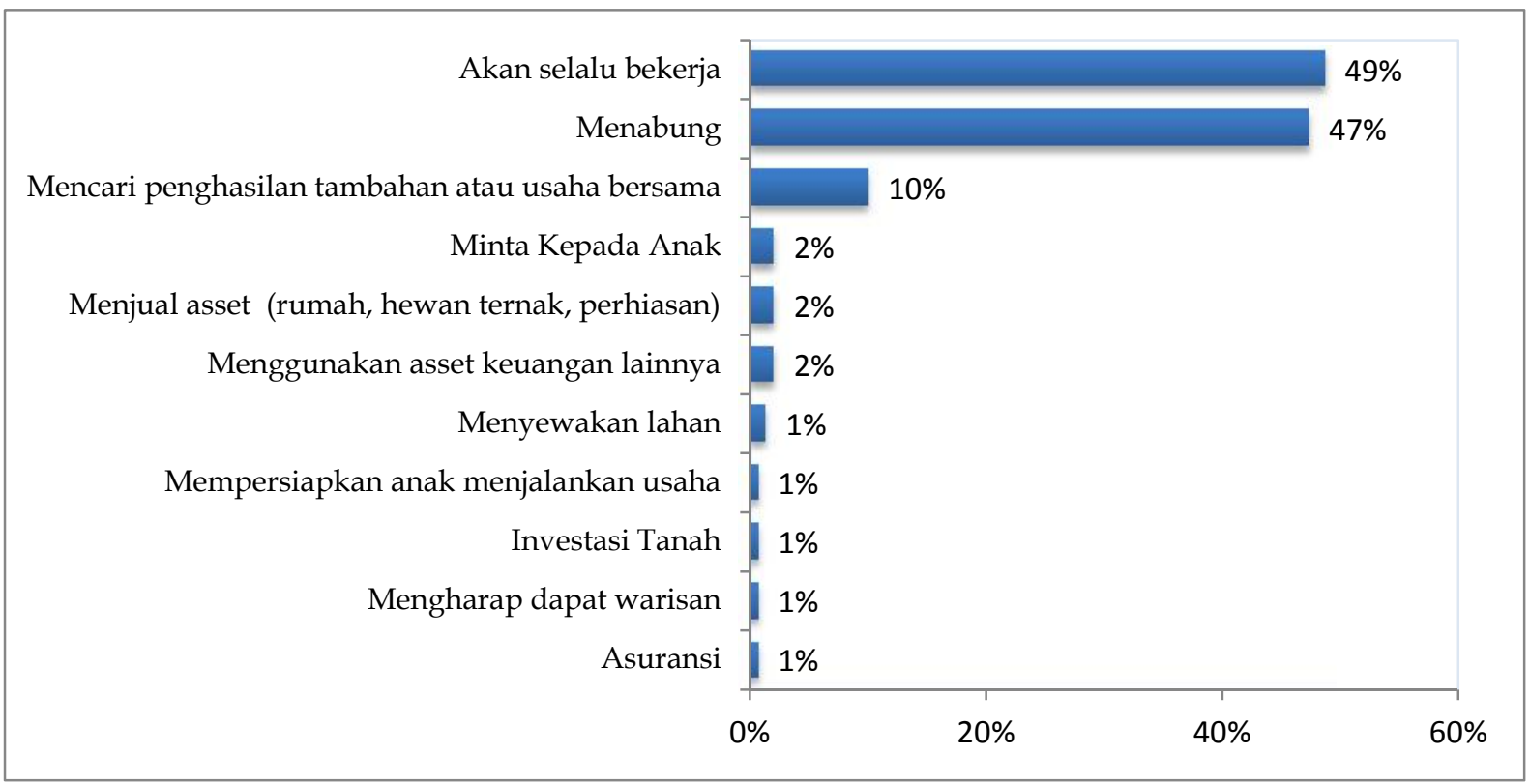

\section{Gambar 12 \\ Rencana yang sudah dilaksanankan \\ Sumber: Data Tahun 2017 diolah}

Sebagian besar responden sebesar $75 \%$ anak akan menanggung pengeluaran dan kebutuhan sehari-hari di masa tua nanti, sedangkan $25 \%$ anak tidak akan menanggung pengeluaran dan kebutuhan seharihari di masa tua nanti. Untuk responden yang berusia diatas 60 tahun, semua responden merasa cukup untuk memenuhi kebutuhan sehari-hari dimasa tuanya. Bagaimana cara memastikan memiliki uang yang cukup untuk menutupi pengeluaran dapat terlihat pada gambar 13 berikut. Berdasarkan gambar 13 cara memastikan memiliki uang yang cukup untuk menutupi pengeluaran, responden sebagian besar menjawab sebanyak $64 \%$ akan selalu bekerja dan menabung (40\%), sedangkan $28 \%$ menjual aset, $28 \%$ meminta bantuan keluarga, $8 \%$ mencari penghasilan tambahan atau usaha dan $4 \%$ menggunakan aset keuangan lainnya.

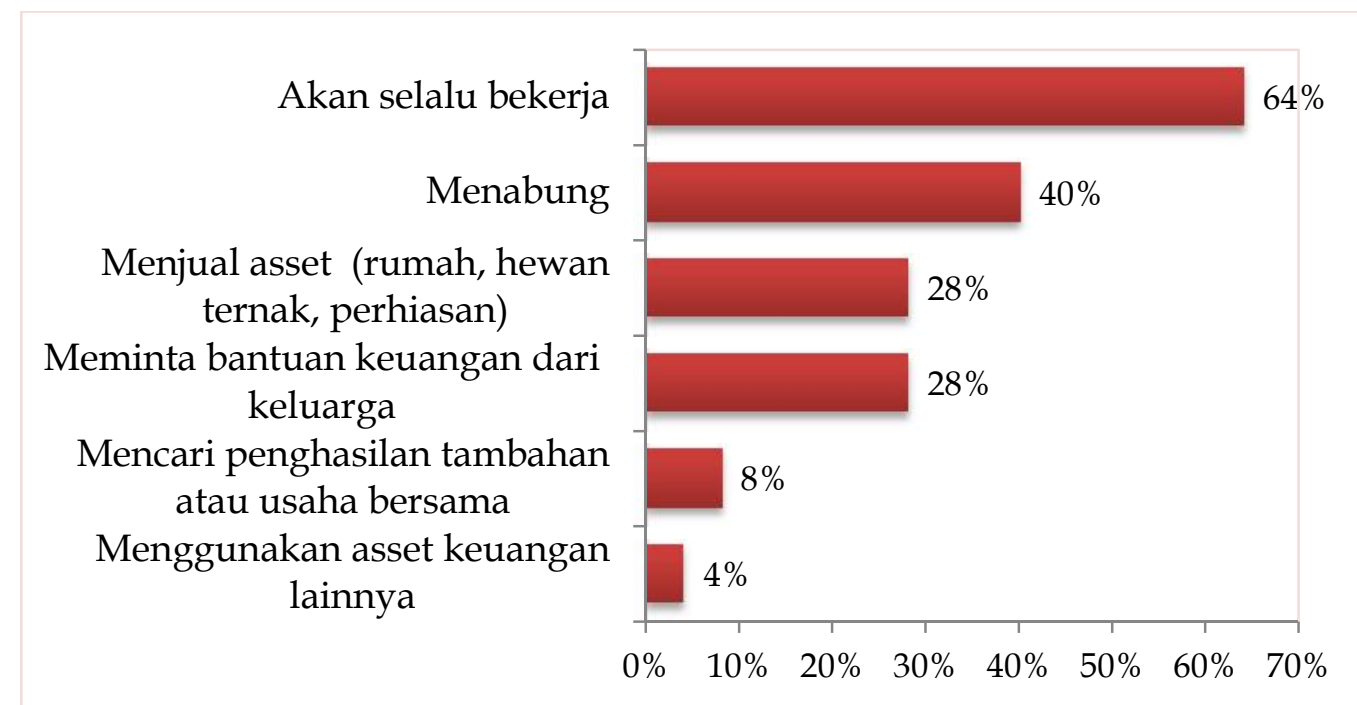

Gambar 13

Cara menutupi kebutuhan di masa tua

Sumber: Data Tahun 2017 diolah 


\section{Perencanaan Masa Depan Anak}

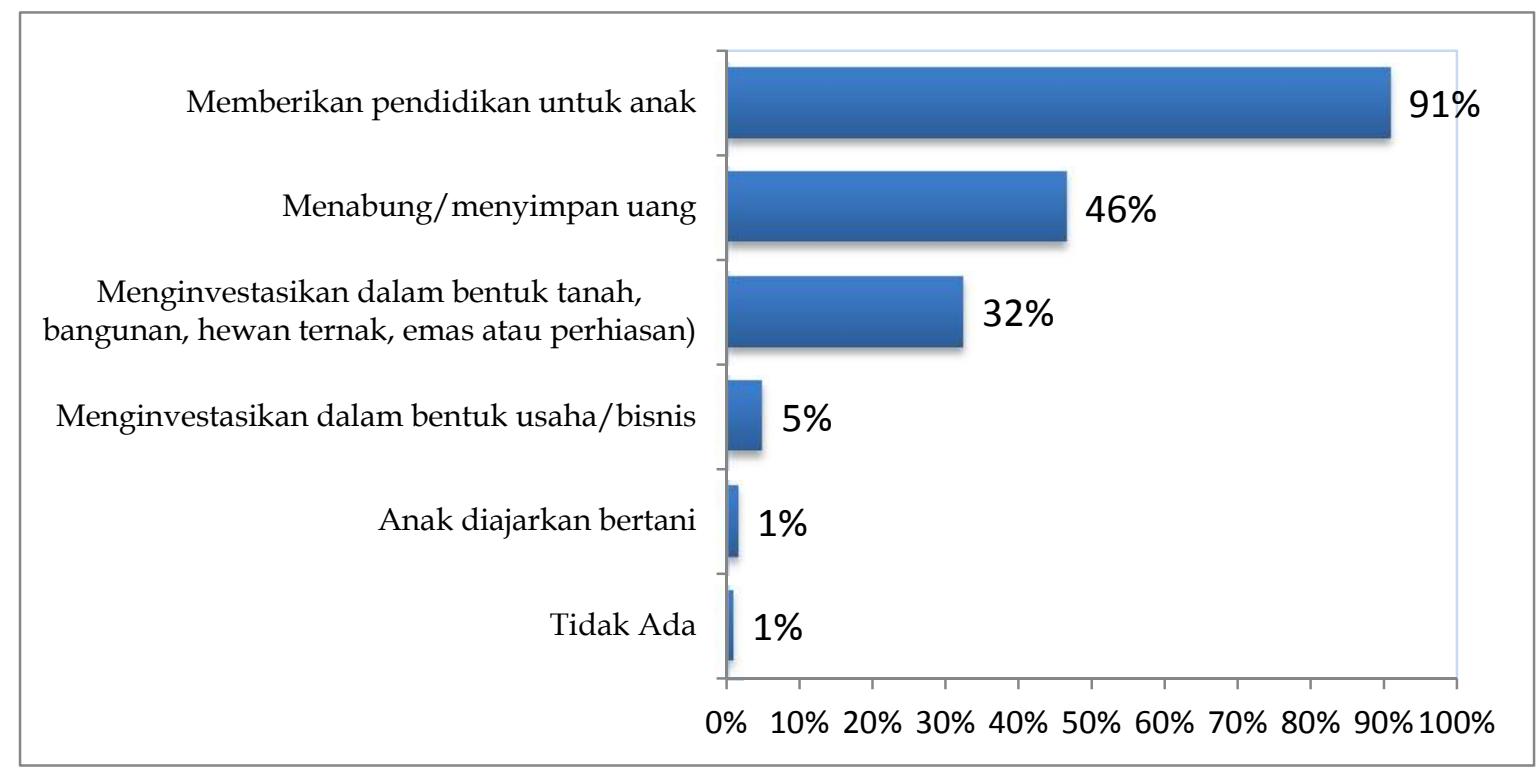

\section{Gambar 14 \\ Cara Merencanakan Masa Depan Anak \\ Sumber: Data Tahun 2017 diolah}

Pada saat ini semua Responden tidak menerima pensiun dan secara pribadi tidak mengikuti program pensiun atau program Dana Pensiun Lembaga Keuangan (DPLK). Sebagian besar responden yaitu 91\% merencanakan masa depan anak dengan memberikan pendidikan untuk anak, sebanyak
$46 \%$ responden menggunakan cara dengan menabung, 32\% responden dengan menginvestasikan dalam bentuk tanah, rumah, 5\% responden menginvestasikan dalam bentuk usaha atau bisnis, sebanyak $1 \%$ anak diajarkan berani.

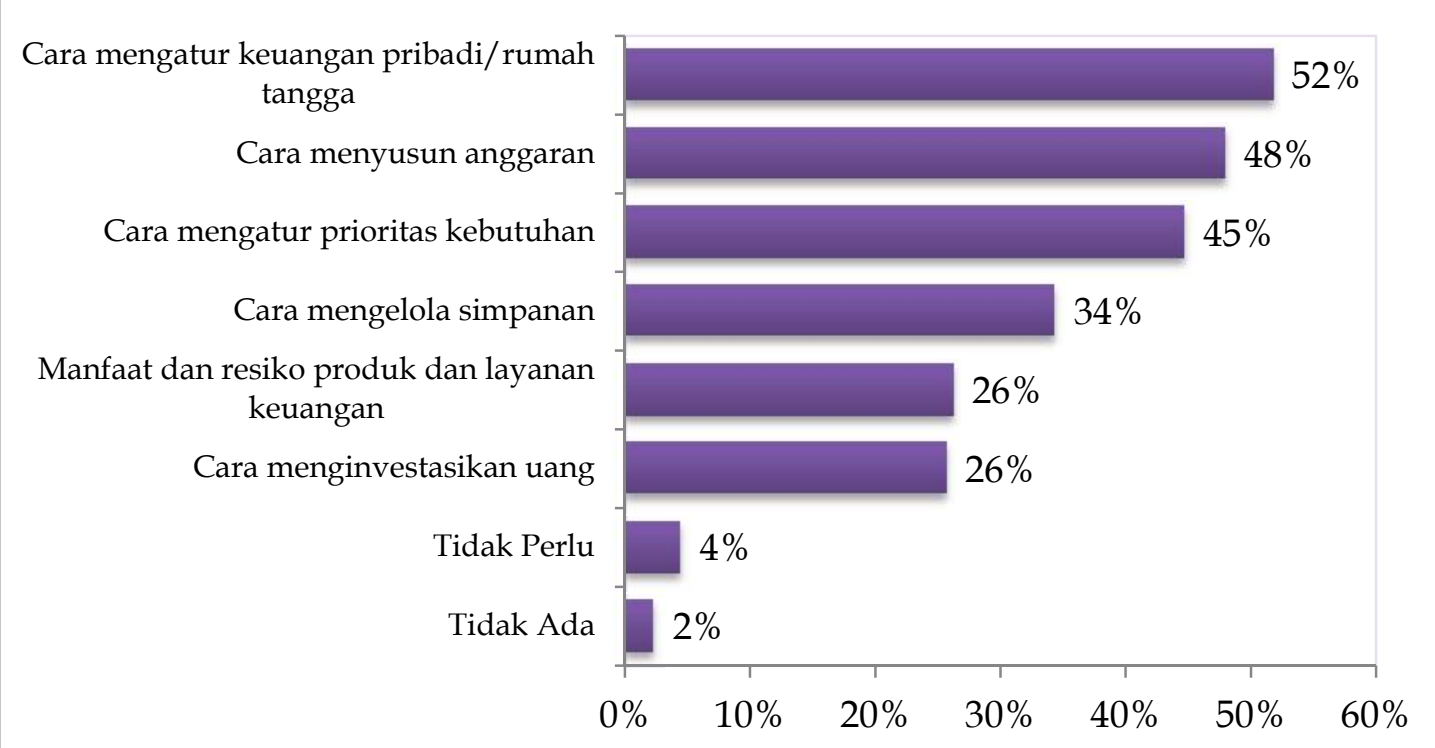

Gambar 15

Sumber: Data Tahun 2017 diolah

\section{Informasi yang diperlukan}




\section{Informasi yang diperlukan}

Dari gambar 15, sebagian besar responden yaitu $52 \%$ memerlukan informasi cara mengatur keuangan pribadi atau rumah tangga, $48 \%$ responden membutuhkan informasi cara menyusun anggaran, $45 \%$ responden membutuhkan informasi cara mengatur prioritas kebutuhan, 34\% responden membutuhkan informasi cara mengelola simpanan, $26 \%$ responden membutuhkan informasi manfaat dan resiko produk layanan, dan sisanya merasa tidak membutuhkan infor masi.

\section{Pengetahuan yang diprioritaskan untuk diketahui}

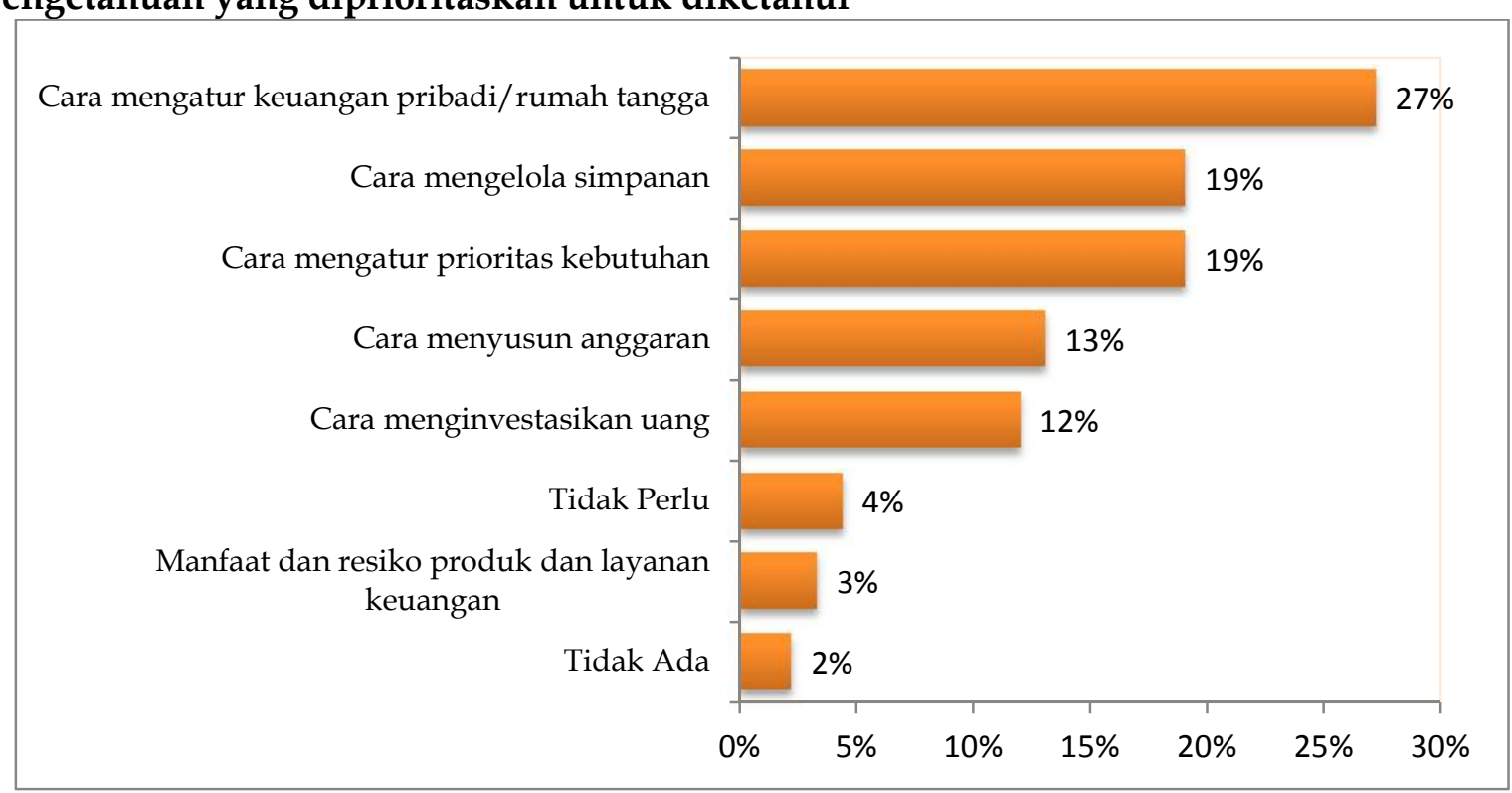

\section{Gambar 16 \\ Sumber: Data Tahun 2017 diolah \\ Pengetahuan yang diprioritaskan}

Dari gambar 16, responden sebagian besar $27 \%$ memprioritaskan informasi tentang cara mengatur keuangan, 19\% cara mengelola simpanan, $19 \%$ cara mengatur prioritas kebutuhan, sebanyak $13 \%$ memprioritaskan cara menyusun anggaran, 12\% memprioritaskan cara menginvestasikan uang dan sisanya tidak perlu.

\section{Edukasi Keuangan}

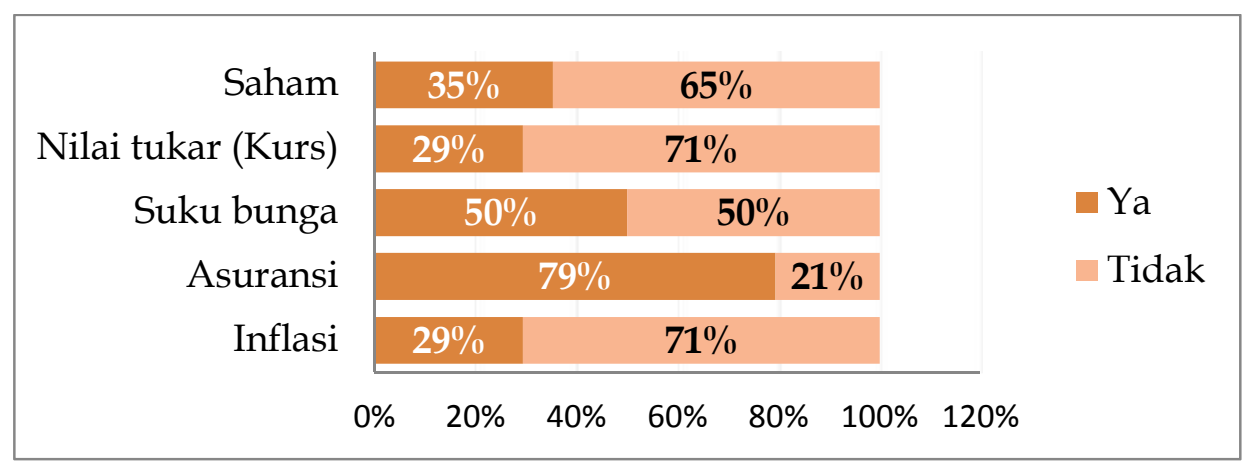

Gambar 17

Pernah mendengar istilah keuangan

Sumber: Data Tahun 2017 diolah 
Dari gambar 17, sebagian besar responden sebanyak $79 \%$ pernah mendengar istilah asuransi, 50\% responden pernah mendengar istilah suku bunga, 35\% responden pernah mendengar istilah saham dan hanya $29 \%$ responden yang pernah mendengar istilah kurs dan inflasi.
Pada gambar 18, istilah keuangan yang diketahui artinya oleh responden sebagian besar adalah Asuransi sebanyak 58\%, sebanyak $55 \%$ mengetahui arti suku bunga, $57 \%$ responden mengetahui arti kurs, 46\% responden mengetahui arti saham dan hanya $31 \%$ responden mengetahui arti inflasi.

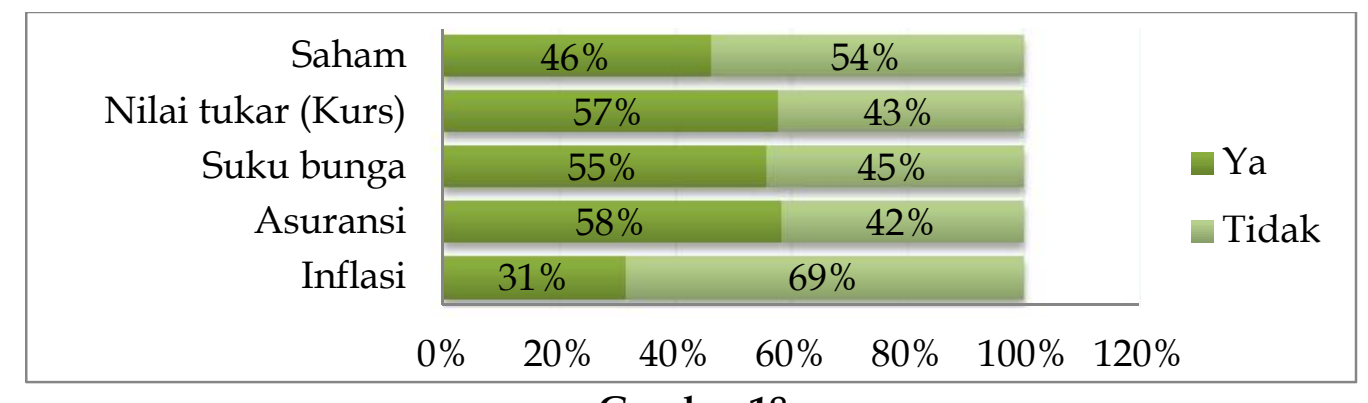

Gambar 18

Sumber: Data Tahun 2017 diolah

\section{Arti istilah keuangan}

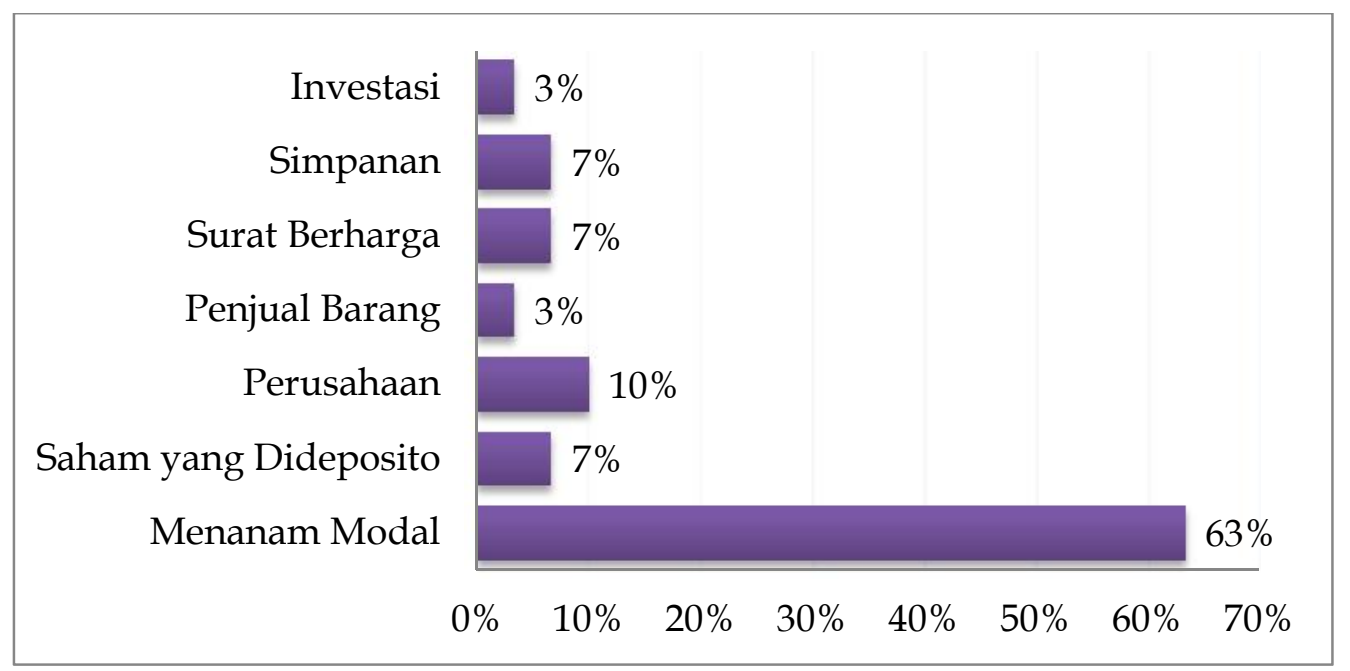

Sumber: Data Tahun 2017 diolah

\section{Gambar 19}

\section{Arti istilah saham}

Dari gambar 19, sebagian besar responden mengartikan istilah saham sebesar $63 \%$ adalah menanam modal, $10 \%$ responden mengartikan perusahaan, sebanyak $7 \%$ mengartikan simpanan, surat berharga dan saham yang dideposito, hanya 3\% yang mengartikan istilah saham adalah investasi dan penjual barang.

\section{Pengetahuan terkait lembaga keuangan}

Berdasarkan tabel 3 pengenalan terhadap lembaga keuangan, 100\% responden mengenal Bank, 99\% responden mengenal kantor pos dan koperasi. Sebanyak 97\% responden mengenal pegadaian, sebanyak $94 \%$ responden mengenal mesin ATM. Sebanyak $80 \%$ responden mengenal asuransi, $62 \%$ responden mengenal jasa pengiriman uang, 52\% responden mengenal perusahaan pembiayaan/multifinance, $39 \%$ responden mengenal BMT, $28 \%$ responden mengenal dana pensiun, $14 \%$ responden mengenal perusahaan efek atau sekuritas dan hanya $2 \%$ yang mengenal agen keuangan digital. 
Tabel 3

Mengenal Lembaga Keuangan

\begin{tabular}{lcccc}
\hline \multicolumn{1}{c}{ Mengenal } & Ya & Persen & Tidak & Persen \\
\hline Bank & 184 & $100 \%$ & 0 & $0 \%$ \\
Asuransi & 148 & $80 \%$ & 36 & $20 \%$ \\
Perusahaan & & & & \\
pembiayaan/multifinance & 95 & $52 \%$ & 89 & $48 \%$ \\
Dana Pensiun & 52 & $28 \%$ & 132 & $72 \%$ \\
Perusahaan efek/sekuritas & 25 & $14 \%$ & 159 & $86 \%$ \\
Pegadaian & 178 & $97 \%$ & 6 & $3 \%$ \\
Kantor pos & 183 & $99 \%$ & 1 & $1 \%$ \\
Koperasi & 183 & $99 \%$ & 1 & $1 \%$ \\
BMT & 71 & $39 \%$ & 113 & $61 \%$ \\
Agen keuangan Digital/Laku & & & & \\
Pandai & 3 & $2 \%$ & 181 & $98 \%$ \\
Mesin ATM & 173 & $94 \%$ & 11 & $6 \%$ \\
Jasa Pengiriman Uang & 114 & $62 \%$ & 70 & $38 \%$ \\
\hline
\end{tabular}

Sumber: Data Tahun 2017 diolah

\section{Hubungan Antara Tingkat Pengetahuan Dengan Tingkat Penggunaan Produk Lembaga Keuangan}

Hasil survei tidak hanya mengukur literasi keuangan responden saja, namun juga mengukur peranan literasi keuangan dalam pengambilan keputusan keuangan salah satunya adalah pengunaan produk lembaga keuangan. Berdasarkan hasil korelasi spearman menunjukkan nilai korelasi sebesar 0,372 dengan nilai probabilitas $(0,000)$. Karena nilai probabilitas lebih kecil dari alpha 5\% artinya terdapat hubungan yang significant dan positif antara pengetahuan terhadap lembaga keuangan dengan tingkat penggunaan produk lembaga keuangan. Semakin tinggi tingkat pengetahuan petani terhadap lembaga keuangan maka semakin tinggi pula tingkat penggunaan produk lembaga keuangan.

\section{SIMPULAN DAN SARAN \\ Simpulan}

(1) Petani holtikultura di tiga wilayah survei memiliki penguasaan luas lahan yang berbeda-beda serta jenis tanaman yang diusahakan juga berbeda-beda. Hal ini sangat berpengaruh terhadap penghasilan yang mereka terima; (2) Dalam mengelola keuangan baru sebagian kecil petani yang menggunakan lembaga keuangan baik untuk menyimpan maupun meminjam. Untuk peminjaman dana dalam jumlah tertentu dan bersifat mendadak petani lebih mengandalkan pinjam dari teman atau keluarga/famili. Untuk keperluan modal usaha cukup banyak petani yang sudah memanfaatkan lembaga keuangan formal seperti Bank; (3) Tidak lebih dari 6\% petani yang merencanakan pengeluaran rumah tangga dan menjalankannya secara konsisten. Hal ini sangat mempengaruhi perilaku mereka dalam pengelolaan keuangannya; (4) Pengenalan petani terhadap lembagalembaga keuangan dapat dikatakan sangat baik, kecuali jasa pengiriman uang dan lembaga pembiayaan. Sementara untuk agen keuangan digital/laku pandai masih sangat rendah; (5) Saat ini petani sangat membatasi peminjaman uang (kredit) melalui bank, karena petani belum membutuhkannya dan takut tidak dapat mengembalikannya, namun demikian sebagian petani membutuhkannya; (6) Terdapat hubungan yang signifikan dan positif antara pengetahuan terhadap lembaga keuangan dengan tingkat 
penggunaan produk lembaga keuangan. Semakin tinggi tingkat pengetahuan petani terhadap lembaga keuangan maka semakin tinggi pula tingkat penggunaan produk lembaga keuangan.

\section{Saran}

Berdasarkan hasil temuan dalam penelitian ini, maka saran untuk penelitian berikutnya adalah: (1) Melakukan rancangan kuesioner yang lebih baik, dengan melakukan perbaikan kuesioner pada pertanyaan yang mewakili indikator dalam penelitian agar mampu mengukur indikator dalam model penelitian; (2) Melakukan penelitian dengan sampel yang lebih besar dan mewakili petani berbagai wilayah di Indonesia sehingga hasilnya mampu menggambarkan kondisi real petani di Indonesia dalam menggunakan produk LKD; (3) Melakukan penelitian yang mampu menggambarkan variasi petani di Indonesia tidak hanya dari petani hortikultura saja tetapi dari jenis tanaman lainnya; (4) Lembaga keuangan memerlukan program literasi dan inklusi keuangan yang akurat untuk meningkatkan bisnisnya di kalangan petani dengan memahami bahwa peningkatan pengetahuan petani terhadap produk keuangan adalah penting.

\section{DAFTAR PUSTAKA}

Abdurachman, A., A. Mulyani, dan N. L. Nurida. 2009. Kondisi dan Antisipasi Keterbatasan Lahan Pertanian di Pulau Jawa. Jurnal Pengembangan Inovasi Pertanian 2(4): 283-285.

ASEAN Development Bank. 2014. Financial Inclusion in Asia Country Surveys. Mandaluyong (PH): ASEAN Development Bank.

Bank Indonesia. 2014. Booklet Keuangan Inklusif. Jakarta (ID): Bank Indonesia.

Behrman, J. R., O. S. Mitchell, C. K. Soo, dan D. Brava. 2012. How Financial Literacy Affects Household Wealth Accumulation. The American Economic Review 102(3): 300-304.
Bucher-Koenen, T. dan A. Lusardi. 2011. Financial Literacy and Retirement Planning in Germany. Journal of Pension Economics and Finance 10(4): 565-584.

Bhushan, P. dan Y. Medury. 2013. Financial Literacy and its Determinants. International Journal of Engineering, Business and Enterprise Applications 4(2): 155160.

Chen, H. dan R. P. Volpe. 1998. An Analysis of Personal Financial Literacy Among College Students. Financial Services Review 72(2): 107-128.

Huston, S. J. 2010. Measuring Financial Literacy. The Journal of Consumer Affairs 44(2): 296-316.

Krishna, A., R. Rofaida, dan M. Sari. 2010. Analisis Tingkat Literasi Keuangan di Kalangan Mahasiswa dan Faktor-faktor yang Mempengaruhinya (Survey pada Mahasiswa Universitas Pendidikan Indonesia). Proceedings of The 4th International Conference on Teacher Education. Join Conference UPI \& UPSI Bandung, Indonesia, 8-10 November 2010.

Lalrinmawia, M. dan H. Gupta. 2015. Literacy dan Knowledge: Farmers' Financial Inclusion Feasibility. SCMS Journal of Indian Management 12(3): 17-24.

Lusardi, A. dan O. S. Mitchell. 2014. The Economic Importance of Financial Literacy: Theory and Evidence. Journal of Economic Literature 52(1): 5-44.

Mendari, A. S. dan S. S. Kewal. 2013. Tingkat Literasi Keuangan di Kalangan Mahasiswa STIE MUSI. Journal Economia 9(2): 130-140.

Otoritas Jasa Keuangan. 2015. Strategi Nasional Literasi Keuangan Indonesia. Direktorat Literasi dan Edukasi Keuangan.

President's Advisory Council on Financial Capability. 2013. Final Report President's Advisory Council on Financial Capability. January 29, 2013.

Ravikumar, R., S. D. Sivakumar, M. Jawaharlal, N. V. Palanichamy, D. Sureshkumar. 2013. Assessment of Farm Financial Literacy among Jasmine Growers in 
Tamilnadu, India. Journal of Developing Country Studies 3(13): 67-75.

Robb, C. A. dan R. N. James. 2009. Associations between Individual Characteristics and Financial Knowledge among College Students. Journal of Personal Finance 8: 170-184.

Salehin, M. M., M. S. Kabir, K. M. Morshed, K. S. Farid. 2009. Socioeconomic Changes of Farmers due to Adoption of Rice Production Technologies in Selected Areas of Sherpur District. Journal of the Bangladesh Agricultural University 7(2): 335-341.

Shen, C. H., S. J. Lin, D. P. Tang, dan Y. J. Hsiao. 2015. The Relationship between Financial Disputes and Financial Literacy. Pacific-Basin Finance Journal 36: 46-65
Taft, M. K., Z. Z. Hosein, S. M. T. Mehrizi, dan A. Roshan. 2013. The Relation between Financial Literacy, Financial Wellbeing and Financial Concerns. International Journal of Business and Management 8(11): 63-75.

Widyawati, I. 2012. Faktor-Faktor yang Mempengaruhi Literasi Finansial Mahasiswa Fakultas Ekonomi dan Bisnis Universitas Brawijaya. Assets: Jurnal Akuntansi dan Pendidikan 1(1): 89-99.

Xiao, J. J., S. Shim, B. Barber, dan A. Lyons. 2007. Academic Success and Well-Being of College Students: Financial Behaviors Matter. America Institute for Consumer Financial Education and Research. 